University of Nebraska - Lincoln

DigitalCommons@University of Nebraska - Lincoln

Faculty Publications in the Biological Sciences

Papers in the Biological Sciences

2018

\title{
CD32 is expressed on cells with transcriptionally active HIV but does not enrich for HIV DNA in resting T cells
}

\author{
Mohamed Abdel-Mohsen \\ The Wistar Institute \\ Leticia Kuri-Cervantes \\ University of Pennsylvania \\ Judith Grau-Exposito \\ Universitat Autònoma de Barcelona \\ Adam M. Spivak \\ University of Utah School of Medicine \\ Racheal A. Nell \\ University of Utah School of Medicine \\ Follow this and additional works at: https://digitalcommons.unl.edu/bioscifacpub \\ See next page for additional authors \\ Part of the Biology Commons
}

Abdel-Mohsen, Mohamed; Kuri-Cervantes, Leticia; Grau-Exposito, Judith; Spivak, Adam M.; Nell, Racheal A.; Tomescu, Costin; Vadrevu, Surya Kumari; Giron, Leila B.; Serra-Peinado, Carla; Genesca, Meritxell; Castellvi, Josep; Wu, Guoxin; Del Rio Estrada, Perla M.; Gonzalez-Navarro, Mauricio; Lynn, Kenneth; King, Collin T.; Vemula, Sai; Cox, Kara; Wan, Yanmin; Li, Qingsheng; Mounzer, Karam; Kostman, Jay; Frank, lan; Paiardini, Mirko; Hazuda, Daria; Reyes-Teran, Gustavo; Richman, Douglas; Howell, Bonnie; Tebas, Pablo; Martinez-Picado, Javier; Planelles, Vicente; Buzon, Maria J.; Betts, Michael R.; and Montaner, Luis J., "CD32 is expressed on cells with transcriptionally active HIV but does not enrich for HIV DNA in resting T cells" (2018). Faculty Publications in the Biological Sciences. 762.

https://digitalcommons.unl.edu/bioscifacpub/762

This Article is brought to you for free and open access by the Papers in the Biological Sciences at DigitalCommons@University of Nebraska - Lincoln. It has been accepted for inclusion in Faculty Publications in the Biological Sciences by an authorized administrator of DigitalCommons@University of Nebraska - Lincoln. 


\section{Authors}

Mohamed Abdel-Mohsen, Leticia Kuri-Cervantes, Judith Grau-Exposito, Adam M. Spivak, Racheal A. Nell, Costin Tomescu, Surya Kumari Vadrevu, Leila B. Giron, Carla Serra-Peinado, Meritxell Genesca, Josep Castellvi, Guoxin Wu, Perla M. Del Rio Estrada, Mauricio Gonzalez-Navarro, Kenneth Lynn, Collin T. King, Sai Vemula, Kara Cox, Yanmin Wan, Qingsheng Li, Karam Mounzer, Jay Kostman, Ian Frank, Mirko Paiardini, Daria Hazuda, Gustavo Reyes-Teran, Douglas Richman, Bonnie Howell, Pablo Tebas, Javier Martinez-Picado, Vicente Planelles, Maria J. Buzon, Michael R. Betts, and Luis J. Montaner 


\title{
CD32 is expressed on cells with transcriptionally active HIV but does not enrich for HIV DNA in resting T cells
}

\author{
Mohamed Abdel-Mohsen, ${ }^{1 *}$ Leticia Kuri-Cervantes, ${ }^{2 *}$ Judith Grau-Exposito, ${ }^{3 *}$ Adam M. Spivak, ${ }^{4}$ \\ Racheal A. Nell, ${ }^{4}$ Costin Tomescu, ${ }^{1}$ Surya Kumari Vadrevu, ${ }^{1}$ Leila B. Giron, ${ }^{1}$ Carla Serra-Peinado, ${ }^{3}$ \\ Meritxell Genescà, ${ }^{3}$ Josep Castellví, ${ }^{5}$ Guoxin Wu, ${ }^{6}$ Perla M. Del Rio Estrada, ${ }^{7}$ Mauricio González-Navarro, ${ }^{7}$ \\ Kenneth Lynn, ${ }^{1,2,8}$ Colin T. King, ${ }^{9}$ Sai Vemula, ${ }^{6}$ Kara Cox,${ }^{6}$ Yanmin Wan, ${ }^{10}$ Qingsheng Li, ${ }^{10}$ \\ Karam Mounzer, ${ }^{8}$ Jay Kostman, ${ }^{8}$ Ian Frank, ${ }^{2}$ Mirko Paiardini, ${ }^{9}$ Daria Hazuda, ${ }^{6}$ Gustavo Reyes-Terán, ${ }^{7}$ \\ Douglas Richman, ${ }^{11}$ Bonnie Howell, ${ }^{6}$ Pablo Tebas, ${ }^{2}$ Javier Martinez-Picado, ${ }^{12,13,14}$ Vicente Planelles, ${ }^{4}$ \\ Maria J. Buzon, ${ }^{3 \dagger}$ Michael R. Betts, ${ }^{2 \dagger}$ Luis J. Montaner ${ }^{1 \dagger}$
}

\begin{abstract}
The persistence of HIV reservoirs, including latently infected, resting $\mathrm{CD} 4^{+} \mathrm{T}$ cells, is the major obstacle to cure HIV infection. $\mathrm{CD} 32 \mathrm{a}$ expression was recently reported to mark $\mathrm{CD} 4^{+} \mathrm{T}$ cells harboring a replication-competent HIV reservoir during antiretroviral therapy (ART) suppression. We aimed to determine whether CD32 expression marks HIV latently or transcriptionally active infected $\mathrm{CD}^{+} \mathrm{T}$ cells. Using peripheral blood and lymphoid tissue of ART-treated $\mathrm{HIV}^{+}$or $\mathrm{SIV}^{+}$subjects, we found that most of the circulating memory CD32 ${ }^{+} \mathrm{CD}_{4}^{+} \mathrm{T}$ cells expressed markers of activation, including CD69, HLA-DR, CD25, CD38, and Ki67, and bore a $\mathrm{T}_{\mathrm{H}} 2$ phenotype as defined by CXCR3, CCR4, and CCR6. CD32 expression did not selectively enrich for HIV- or SIV-infected CD4 ${ }^{+} \mathrm{T}$ cells in peripheral blood or lymphoid tissue; isolated $\mathrm{CD} 32^{+}$resting $\mathrm{CD}_{4}^{+} \mathrm{T}$ cells accounted for less than $3 \%$ of the total HIV DNA in CD4 ${ }^{+}$ T cells. Cell-associated HIV DNA and RNA loads in $\mathrm{CD}^{+}{ }^{+}$cells positively correlated with the frequency of $\mathrm{CD}^{2} 2^{+}$ $\mathrm{CD} 9^{+} \mathrm{CD}^{+} \mathrm{T}$ cells but not with $\mathrm{CD} 32$ expression on resting $\mathrm{CD} 4^{+} \mathrm{T}$ cells. Using RNA fluorescence in situ hybridization, CD32 coexpression with HIV RNA or p24 was detected after in vitro HIV infection (peripheral blood mononuclear cell and tissue) and in vivo within lymph node tissue from HIV-infected individuals. Together, these results indicate that CD32 is not a marker of resting CD4 ${ }^{+}$T cells or of enriched HIV DNA-positive cells after ART; rather, CD32 is predominately expressed on a subset of activated $\mathrm{CD}^{+}{ }^{+} \mathrm{T}$ cells enriched for transcriptionally active HIV after long-term ART.
\end{abstract}

\section{INTRODUCTION}

The main barrier to HIV eradication is the ability of HIV-1 to establish latency in long-lived resting $\mathrm{CD}^{+} \mathrm{T}$ cells $(1,2)$, which persist in blood and tissues (3-6). Quiescent $\mathrm{CD} 4^{+} \mathrm{T}$ cells harboring latent HIV do not produce virus until they are activated to produce infectious virus (7-14). These latently infected cells are likely the source of rebound after interruption of antiretroviral therapy (ART), and their continual reactivation in vivo probably contributes to ongoing immune activation, inflammation, and organ damage that persists even under suppressive ART (15-23).

Despite nearly two decades of research, it remains unclear what mechanisms govern latency in vivo and persistence of HIV after therapy. One major obstacle to progress is the inability to distinguish and identify latently infected cells in vivo, which has precluded a full

\footnotetext{
${ }^{1}$ The Wistar Institute, Philadelphia, PA 19104, USA. ${ }^{2}$ Department of Microbiology, Perelman School of Medicine, University of Pennsylvania, Philadelphia, PA 19104, USA. ${ }^{3}$ Department of Infectious Diseases, Hospital Universitari Vall d'Hebrón, Institut de Recerca (VHIR), Universitat Autònoma de Barcelona, Barcelona 08035, Spain. ${ }^{4}$ University of Utah School of Medicine, Salt Lake City, UT 84132, USA. ${ }^{5}$ Department of Pathology, Hospital Universitari Vall d'Hebrón, Barcelona 08035, Spain. ${ }^{6}$ Merck \& Co. Inc., Kenilworth, NJ 07033, USA. Instituto Nacional de Enfermedades Respiratorias, Tlalpan 14080, Mexico City, Mexico. ${ }^{8}$ Jonathan Lax Center, Philadelphia FIGHT, Philadelphia, PA 19107, USA. ${ }^{9}$ Emory University, Atlanta, GA 30322, USA. ${ }^{10}$ University of Nebraska-Lincoln, Lincoln, NE 68588, USA. ${ }^{11}$ Veterans Affairs San Diego Healthcare System and University of California, San Diego, San Diego, CA 92093, USA. ${ }^{12}$ IrsiCaixa AIDS Research Institute, Badalona 08916, Barcelona, Spain. ${ }^{13}$ University of Vic-Central University of Catalonia (UVic-UCC), Vic 08500, Barcelona, Spain. ${ }^{14}$ Catalan Institution for Research and Advanced Studies (ICREA), Barcelona 08908, Catalonia, Spain. *These authors contributed equally to this work.

+Corresponding author. Email: montaner@wistar.org (L.J.M.); mariajose.buzon@ vhir.org (M.J.B.); betts@pennmedicine.upenn.edu (M.R.B.)
}

understanding of HIV latency and hampered the development of curative strategies. Because latently infected cells express little or no HIV RNA or protein, strategies for eliminating HIV latency will likely require identification of host factors that can be used to identify and target latently infected cells.

Recently, Descours et al. (24) suggested that CD32a (FcyRIIa), an Fc $\gamma$ receptor mainly expressed on myeloid cells and platelets, is a potential biomarker of the $\mathrm{CD} 4^{+} \mathrm{T}$ cell HIV reservoir harboring replication-competent proviruses in ART-suppressed individuals. However, because this report did not exclusively define resting versus activated $\mathrm{CD}^{+} \mathrm{T}$ cells, it remains unclear whether $\mathrm{CD} 32 \mathrm{a}$ is specifically enriched in resting latently infected $\mathrm{CD} 4^{+} \mathrm{T}$ cells. Previous studies have demonstrated that $\mathrm{CD} 32$ is rarely expressed by resting $\mathrm{CD}^{+} \mathrm{T}$ cells $(25,26)$ compared to activated $\mathrm{T}$ cells $(27-29)$, further stressing the need to characterize $\mathrm{CD} 32$ expression on resting $\mathrm{CD} 4^{+} \mathrm{T}$ cells in HIV-infected individuals. To address this issue, we examined whether $\mathrm{CD} 32$ is associated with resting or activated $\mathrm{CD} 4^{+}$ $\mathrm{T}$ cells in ART-treated individuals, whether CD32 expression can enrich for HIV DNA copies in total or resting $\mathrm{CD}^{+} \mathrm{T}$ cells, and whether it aligns with latent or transcriptionally active HIV-infected $\mathrm{CD} 4^{+} \mathrm{T}$ cells.

\section{RESULTS}

$\mathrm{CD}^{+}{ }^{+} \mathrm{CD}^{+} \mathrm{T}$ cells are enriched with activated cells rather than with resting cells

HIV latency has been functionally defined in resting $\mathrm{CD} 4^{+}$lymphocytes $\left(\mathrm{CD}^{+}, \mathrm{CD}^{-} 9^{-}, \mathrm{CD} 25^{-}\right.$, and HLA-DR $\left.{ }^{-}\right)$, which lack expression of virions or viral antigens $(7,30-35)$. We measured $\mathrm{CD}^{+} \mathrm{T}$ cell surface 
expression of CD32 and activation markers [CD69 for early activation, CD25 for intermediate or late activation, and human leukocyte antigen-DR (HLA-DR) for late activation] using flow cytometry on fresh blood from ART-suppressed HIV-infected individuals with $<50$ copies/ml of plasma viral load (VL), HIV-infected individuals with VL $>50$ copies $/ \mathrm{ml}$, and $\mathrm{HIV}^{-}$controls (table S1). We also assessed the expression of CD32 on cryopreserved peripheral blood mononuclear cells (PBMCs) from ART-suppressed HIV-infected individuals. $\mathrm{CD} 32$ was detected on the surface of $\mathrm{CD} 4{ }^{+} \mathrm{T}$ cells from (i) $\mathrm{HIV}^{-}$controls [median, 5.7\%; interquartile range (IQR), 4.1\%], (ii) $\mathrm{HIV}^{+}$individuals with $\mathrm{VL}<50$ copies/ml (median, 4\%; IQR, 1.95\%), and (iii) $\mathrm{HIV}^{+}$individuals with $\mathrm{VL}>50$ copies/ml (median, $3.1 \%$; IQR, 3\%) (Fig. 1A). The frequency of CD32 on fresh $\mathrm{CD}^{+} \mathrm{T}$ cells in ART-suppressed $\mathrm{HIV}^{+}$individuals (median, $4 \%$; IQR, 1.95\%) was significantly higher $(P<0.0001)$ than that on frozen cells (median, $0.41 \%$; IQR, 0.3\%) (Fig. 1B). Despite the frequency difference, there was no phenotypic difference between $\mathrm{CD} 32^{+} \mathrm{CD} 4^{+} \mathrm{T}$ cells from fresh and frozen samples. Following the gating strategy used by Descours et al. (24), we divided $\mathrm{CD} 32^{+} \mathrm{CD} 4^{+} \mathrm{T}$ cells into cells expressing intermediate levels of $\mathrm{CD} 32\left(\mathrm{CD} 32^{\text {intermediate }}\right)$ and cells expressing high levels of CD32 (CD32 hi $)$ (fig. S1). CD $32^{\text {intermediate }}$ was detected on the surface of $\mathrm{CD}^{+}{ }^{+} \mathrm{T}$ cells from (i) $\mathrm{HIV}^{-}$controls (median, 5.0\%; IQR, 4.2\%), (ii) $\mathrm{HIV}^{+}$individuals with $\mathrm{VL}<50$ copies $/ \mathrm{ml}$ (median, 3.9\%; IQR $1.97 \%$ ), and (iii) $\mathrm{HIV}^{+}$individuals with $\mathrm{VL}>50$ copies $/ \mathrm{ml}$ (median, 2.9\%; IQR, 3\%) (Fig. 1C). CD32 ${ }^{\text {hi }}$ was detected on the surface of $\mathrm{CD}^{+} \mathrm{T}$ cells from (i) $\mathrm{HIV}^{-}$individuals (median, $0.26 \%$; IQR, $0.16 \%$ ), (ii) $\mathrm{HIV}^{+}$individuals with $\mathrm{VL}<50$ copies/ml (median, $0.16 \%$; IQR, $0.14 \%$ ), and (iii) $\mathrm{HIV}^{+}$individuals with $\mathrm{VL}>50$ copies $/ \mathrm{ml}$ (median, $0.16 \%$; IQR, 0.06\%) (Fig. 1D).

A higher proportion of $\mathrm{CD} 32^{+} \mathrm{CD} 4^{+} \mathrm{T}$ cells expressed the activation markers CD69, HLA-DR, or CD25 compared to CD $32^{-} \mathrm{CD} 4^{+}$ T cells $\left(P=0.03\right.$ in $\mathrm{HIV}^{-}$individuals, $P<0.0001$ in $\mathrm{HIV}^{+}$individuals

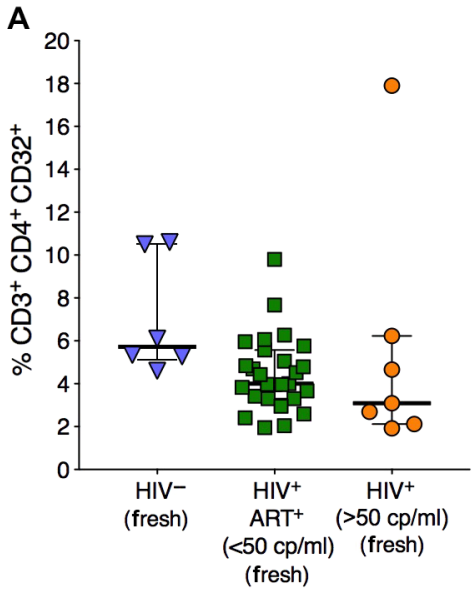

D

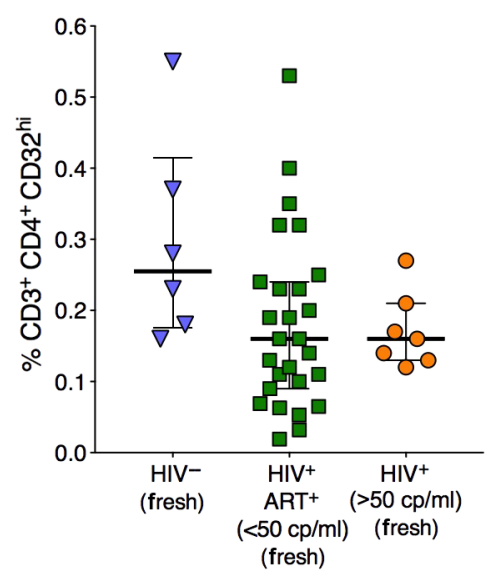

B

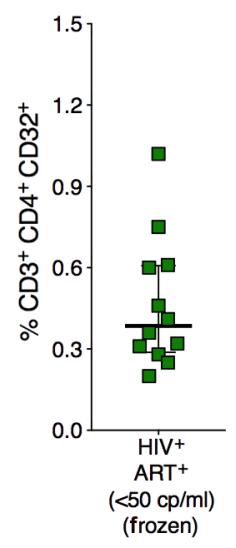

C

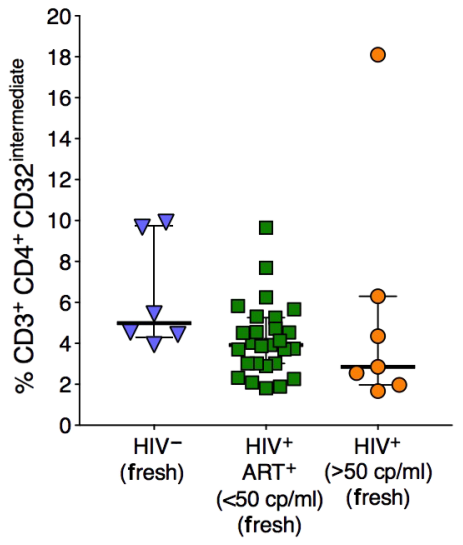

E

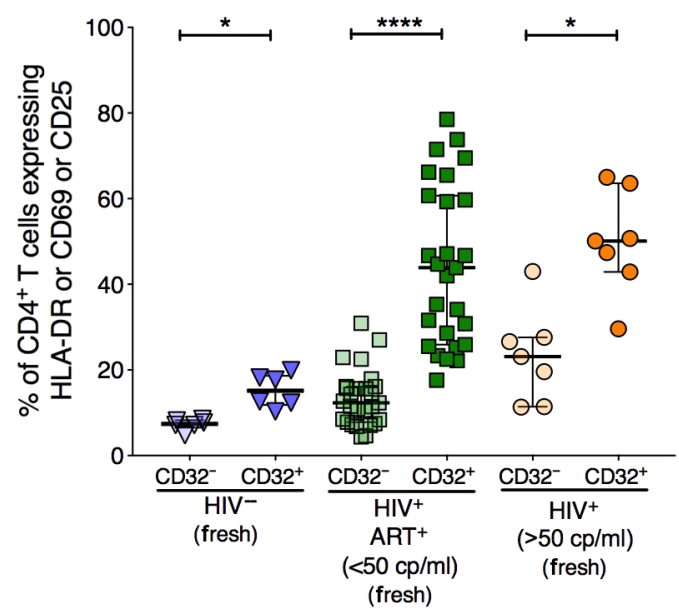

Fig. 1. CD32 ${ }^{+} \mathrm{CD4}^{+} \mathrm{T}$ cells are enriched with activated cells. Freshly isolated peripheral blood mononuclear cells (PBMCs) from $\mathrm{HIV}^{-}$controls, $\mathrm{HIV}^{+}$individuals with $\mathrm{VL}<50$ copies (cp)/ml, and $\mathrm{HIV}^{+}$individuals with VL $>50$ copies/ml were stained for CD32, CD69, HLA-DR, and CD25 on CD4 ${ }^{+} \mathrm{T}$ cells. (A) Percentage of total CD32 ${ }^{+}$within $\mathrm{CD}^{+} \mathrm{T}$ cells. (B) Percentage of total CD32 $2^{+} \mathrm{CD} 4^{+} \mathrm{T}$ cells in cryopreserved PBMCs from HIV ${ }^{+}$individuals with $\mathrm{VL}<50$ copies $/ \mathrm{ml}$. (C) Percentage of CD32 $2^{\text {intermediate }}$ within $\mathrm{CD} 4^{+} \mathrm{T}$ cells. (D) Percentage of total CD32 ${ }^{\text {hi }}$ within $\mathrm{CD} 4^{+} \mathrm{T}$ cells. (E) Percentage of cells expressing at least one of the activation markers human leukocyte antigen-DR (HLA-DR), CD69, and CD25 on CD32 ${ }^{+} \mathrm{CD} 4^{+} \mathrm{T}$ cells and CD32- CD4 ${ }^{+} \mathrm{T}$ cells. Lines and error bars represent median and IQR, respectively. All statistical comparisons were performed using two-tailed Wilcoxon rank tests. $n=6$ for $\mathrm{HIV}^{-}$controls, $n=27$ for $\mathrm{HIV}^{+} \mathrm{ART}^{+}(<50$ copies $/ \mathrm{ml})$ individuals, and $n=7$ for $\mathrm{HIV}^{+}\left(>50\right.$ copies $/ \mathrm{ml}^{2}$ individuals. ${ }^{*} P<0.05$ and ${ }^{* * *} P<0.0001$. 
with $\mathrm{VL}<50$ copies $/ \mathrm{ml}$, and $P=0.016$ in $\mathrm{HIV}^{+}$individuals with $\mathrm{VL}$ $>50$ copies $/ \mathrm{ml}$ ). The frequency of $\mathrm{CD} 32^{+} \mathrm{CD} 4^{+} \mathrm{T}$ cells expressing one or more of the three activation markers (median, $43.9 \%$; IQR, $33 \%$ ) was higher compared to $\mathrm{CD} 32^{-} \mathrm{CD} 4^{+} \mathrm{T}$ cells (median, $12.3 \%$; IQR, 7.8\%) in $\mathrm{HIV}^{+}$ART-suppressed individuals $(P<0.0001)$ (Fig. 1E). The percentages of $\mathrm{CD}_{69}{ }^{+}$, $\mathrm{HLA}-\mathrm{DR}^{+}$, or $\mathrm{CD} 25^{+}$as measured individually were also significantly higher on $\mathrm{CD} 32^{+}$cells compared to CD $32^{-}$cells (fig. S2). These data indicate that activated rather than resting $\mathrm{CD}^{+} \mathrm{T}$ cells are enriched within $\mathrm{CD} 32^{+} \mathrm{CD} 4^{+}$cells.

\section{$\mathrm{CD}^{+} 2^{+}$memory $\mathrm{CD4}^{+} \mathrm{T}$ cells have a $\mathrm{T}_{\mathrm{H}} 2$ phenotype and express activation markers}

We next examined the composition and distribution of CD32 expression in $\mathrm{CD}^{+} \mathrm{T}$ cell subpopulations from PBMC samples of uninfected, ART-suppressed, and untreated viremic HIV-infected donors analyzed by two independent laboratories in Philadelphia and Barcelona (table S3). Flow cytometry gating strategies used for the identification of $\mathrm{CD} 4^{+} \mathrm{T}$ cell subsets and $\mathrm{CD} 32$ expression are shown in fig. S3. We found that the overall distribution of CD32 ${ }^{+}$HLA$\mathrm{DR}^{-} \mathrm{CD} 4^{+} \mathrm{T}$ cells between $\mathrm{HIV}^{-}$and $\mathrm{HIV}$-infected individuals was similar, irrespective of the presence of viremia (Fig. 2A). We next

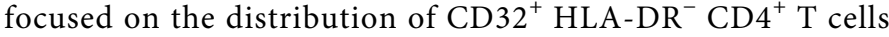
among the different memory $\mathrm{CD}^{+} \mathrm{T}$ cell subsets. We observed that most $\mathrm{CD}_{32}{ }^{+}$cells had either a naïve or a central memory $\mathrm{T}$ cell $\left(\mathrm{T}_{\mathrm{CM}}\right.$ ) phenotype (median percentages/IQR for naïve, 53.2/6.6 in $\mathrm{HIV}^{-}$Philadelphia, 53.3/19.1 in HIV-infected $\mathrm{ART}^{+}{ }_{\text {Barcelona }}$, and 40.9/18.1 in HIV-infected $\mathrm{ART}^{+}$Philadelphia; median percentages/IQR for $\mathrm{T}_{\mathrm{CM}}, 25.3 / 9.2$ in the $\mathrm{HIV}^{-}$Philadelphia and 34.9/10.5 in HIV-infected $\mathrm{ART}^{+}$Philadelphia). Overall, naïve and $\mathrm{T}_{\mathrm{CM}} \mathrm{CD} 4^{+} \mathrm{T}$ cells harbored more than $90 \%$ of all CD $32^{+}$cells found in peripheral blood. We did not observe any significant differences between viremic and ARTtreated subjects.

We further characterized the T helper cell $\left(\mathrm{T}_{\mathrm{H}}\right)$ phenotype of CD32-expressing memory $\mathrm{CD}^{+}{ }^{+} \mathrm{T}$ cells within HIV-infected individuals from the cohort analyzed in Philadelphia. To identify the $\mathrm{T}_{\mathrm{H}}$ phenotype, we analyzed the frequency of follicular helper $\mathrm{T}$ cells $\left(\mathrm{T}_{\text {fh }} ; \mathrm{CXCR}^{+} \mathrm{PD}^{+}\right)$, regulatory $\mathrm{T}$ cells $\left(\mathrm{T}_{\text {regs }} ; \mathrm{CD} 127 \mathrm{lo} /-\mathrm{CD} 25^{+}\right)$, $\mathrm{T}_{\mathrm{H}} 1$ (CXCR $\left.^{+} \mathrm{CCR}^{-} \mathrm{CCR}^{-}\right), \mathrm{T}_{\mathrm{H}} 2\left(\mathrm{CXCR}^{-} \mathrm{CCR}^{+} \mathrm{CCR}^{-}\right)$, and $\mathrm{T}_{\mathrm{H}} 17$ (CXCR3 ${ }^{-} \mathrm{CCR}^{-} \mathrm{CCR}^{+}$) within total memory CD $32^{+} \mathrm{CD}^{+}$ T cells (Fig. 2B). Most cells remained undefined, but in those CD32 ${ }^{+}$ cells for which we could identify defined $\mathrm{T}_{\mathrm{H}}$ subsets, we observed that the frequency of $\mathrm{T}_{\mathrm{H}} 2$ cells was significantly higher than all others $(P<0.05$ for all cases). However, we observed that this enrichment was only found in CD32 ${ }^{+}$HLA-DR ${ }^{+}$cells and CD32- ${ }^{-}$LA-DR ${ }^{+}$ cells, but not in $\mathrm{CD}_{2} 2^{+} \mathrm{HLA}^{-\mathrm{DR}^{-}}$cells. These data suggest that activation, rather than $\mathrm{CD} 32^{+}$expression, skewed the differentiation into $\mathrm{T}_{\mathrm{H}} 2$ in this cohort.

We further found that most memory $\mathrm{CD} 32^{+} \mathrm{CD} 4^{+} \mathrm{T}$ cells expressed one or more activation markers (Fig. 2, C and D), independent of HLA-DR alone. Whereas HLA-DR ${ }^{+}$cells generally expressed other activation markers, CD $32^{+} \mathrm{HLA}_{-} \mathrm{DR}^{-}$cells showed similarly high activation profiles, including significantly higher frequencies of CD38 $8^{+}$ $(P<0.0001)$ and $\mathrm{Ki67}^{+}(P<0.0001)$ cells, compared to CD32 ${ }^{-}$cells. We also observed that memory $\mathrm{CD} 32^{+} \mathrm{CD} 4{ }^{+} \mathrm{T}$ cells had lower frequencies of programmed cell death protein 1 (PD-1) and CD57 when compared with memory $\mathrm{CD}^{-} 2^{-}$cells $(P=0.017$ and $P<0.0001$, respectively). Of note, $\mathrm{CD} 32^{+}$naïve $\mathrm{CD} 4^{+} \mathrm{T}$ cells also had higher frequencies of activation markers compared to CD32 ${ }^{-}$cells $(P=0.035$ for HLA-DR, $P=0.0005$ for CD38, and $P<0.0001$ for Ki67).
Finally, we incorporated the analyzed parameters within memory $\mathrm{CD}_{2} 2^{+}$and $\mathrm{CD} 32^{-} \mathrm{CD} 4^{+} \mathrm{T}$ cells and performed unbiased clustering and principal components analyses (PCAs) of the entire data set (Fig. 2, E and F). These analyses confirmed that $\mathrm{CD} 32^{+}$cells have a phenotype distinctive from $\mathrm{CD}_{3}{ }^{-}$cells, and this phenotype is similar between viremic and aviremic $\mathrm{HIV}^{+}$individuals.

\section{$\mathrm{CD}^{+}{ }^{+}$cells are similar between blood and tonsils of ART-treated $\mathrm{HIV}^{+}$donors}

Given the central importance of lymphoid tissues as a source of the $\mathrm{HIV}$ reservoir during HIV/simian immunodeficiency virus (SIV) infection (3-6), we investigated the frequency of expression of CD $32^{+}$ $\mathrm{CD}^{+} \mathrm{T}$ cells, subset distribution, and phenotype in tonsil samples from ART-treated HIV-infected individuals from the Philadelphia cohort (Fig. 3 and fig. S4). We first compared frequencies of CD32 ${ }^{+}$ cells in four paired PBMC and tonsil samples. We found a higher frequency of $\mathrm{CD}_{2} 2^{+} \mathrm{HLA}-\mathrm{DR}^{+} \mathrm{CD}^{+} \mathrm{T}$ cells in tonsils when compared to blood (median percentages/IQR, 27.7/4.3 and 10.11/11.29, respectively), but this proportion was inverted in CD32 ${ }^{-} \mathrm{HLA}_{-} \mathrm{DR}^{-}$ $\mathrm{CD}^{+} \mathrm{T}$ cells (median percentages/IQR, 89.9/11.3 in blood and $72.3 / 4.3$ in tonsils). These differences did not reach statistical significance, possibly because of the low sample number $(P>0.05$ for all cases; fig. S4, A to C). We first analyzed the distribution of CD $32^{+}$ HLA-DR $^{-} \mathrm{CD}^{+}{ }^{+} \mathrm{T}$ cells in memory subsets in tonsils, and similar to our observation in blood (Fig. 2), $\mathrm{T}_{\mathrm{CM}}$ was the most frequent memory subset (median, 52.8\%; IQR, 24.9\%; Fig. 3A). In contrast to our findings in blood (Fig. 2), we did not see an enrichment of naïve cells

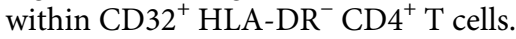

We also characterized the proportions of CD32- and HLA-DRexpressing cells within $\mathrm{CD} 4^{+} \mathrm{T}$ cell subsets (fig. S4D). In contrast with periphery, $\mathrm{T}_{\mathrm{CM}}$ and terminally differentiated memory cells $\left(\mathrm{T}_{\mathrm{TD}}\right)$ had the highest frequency of CD32 ${ }^{+} \mathrm{HLA}_{-} \mathrm{DR}^{-} \mathrm{CD} 4^{+} \mathrm{T}$ cells in the analyzed tonsils (median percentages/IQR, 0.30/0.34 and 0.36/0.78, respectively). Overall, we observed a similar distribution of $\mathrm{CD} 32^{+}$ cells and enrichment of CD32/HLA-DR-expressing cells within CD $4^{+}$ $\mathrm{T}$ cells in tonsils, as we found in blood.

When focusing our analysis on memory $\mathrm{CD}^{+} \mathrm{T}$ cells, we found that the most frequent definable profile within $\mathrm{CD}_{2} 2^{+}$cells was $\mathrm{T}_{\mathrm{H}} 2$, in agreement with our findings in blood, and $\mathrm{T}_{\mathrm{H}} 17$ (median percentages/ IQR, 21.5/14.4 in $\mathrm{T}_{\mathrm{H}} 2$ and 14.8/3.7 in $\mathrm{T}_{\mathrm{H}} 17$; Fig. 3B). Similar to our findings in PBMCs, we found that tonsillar CD $32^{+}$memory $\mathrm{CD} 4^{+}$ $\mathrm{T}$ cells have higher frequencies of $\mathrm{CD} 38^{+}$and $\mathrm{Ki} 67^{+}$cells than their CD $32^{-}$counterparts (Fig. 3, C and D). Furthermore, CD $32^{+}$and CD $32^{-}$ memory $\mathrm{CD}^{+} \mathrm{T}$ cells show different phenotypic profiles (Fig. $3 \mathrm{E}$ ). We further confirmed this enrichment in the frequency of CD $32^{+} \mathrm{CD} 4^{+}$ T cells, compared to CD $32^{-} \mathrm{CD} 4^{+} \mathrm{T}$ cells, expressing HLA-DR and Ki67 in blood and lymph node (LN) cells isolated from five ART-suppressed, SIV-infected rhesus macaques (RMs; fig. S5). Overall, these data demonstrate that the frequency and phenotype of CD $32^{+}$cells in lymphoid tissues analyzed largely parallel those in the peripheral blood.

\section{CD32 expression associates with productive HIV infection in vitro and ex vivo}

To investigate the direct effect of HIV replication on CD32 expression, ex vivo infection kinetics were examined using unstimulated PBMCs from three healthy donors. Cells were infected for up to 6 days and subjected to the RNA fluorescence in situ hybridization (FISH)flow assay for the assessment of CD32, HLA-DR, and PD-1 expression on $\mathrm{HIV}$-infected cells. Productively HIV-infected cells were defined 


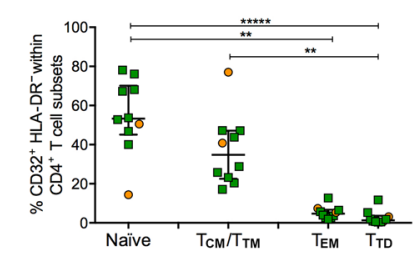

B

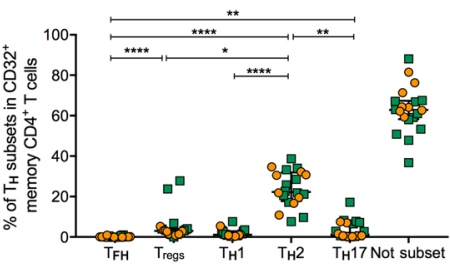

\section{Barcelona (HIV+)} (1)

C

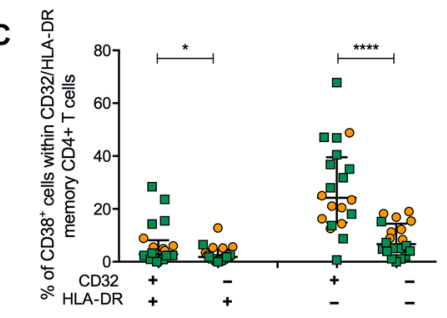

D

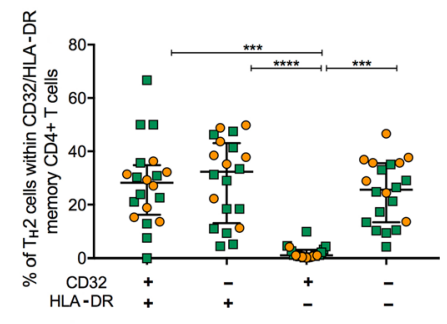

Philadelphia (HIV+)

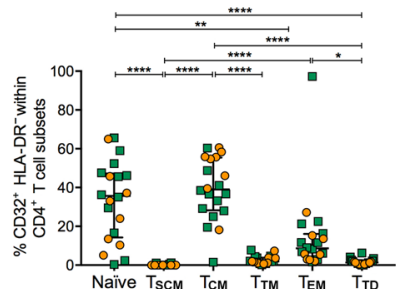

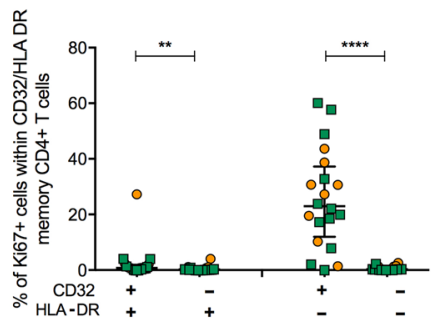
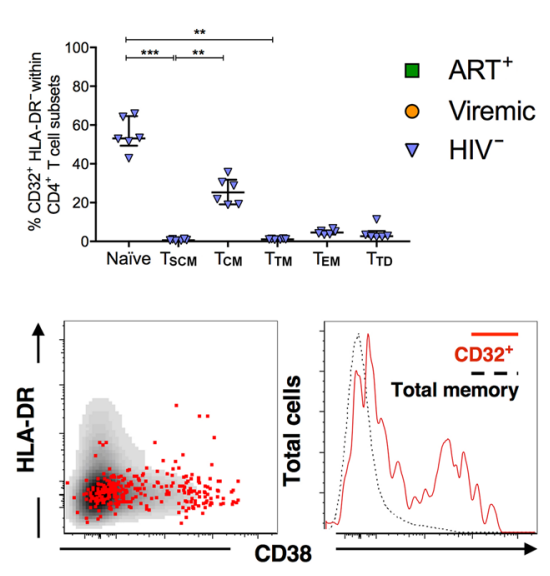

Philadelphia (HIV-)

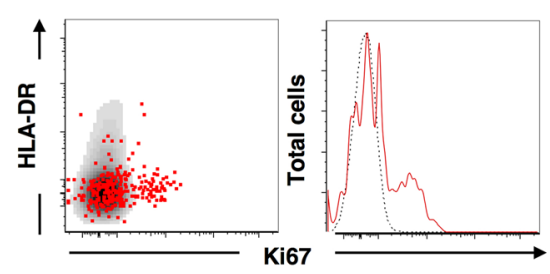

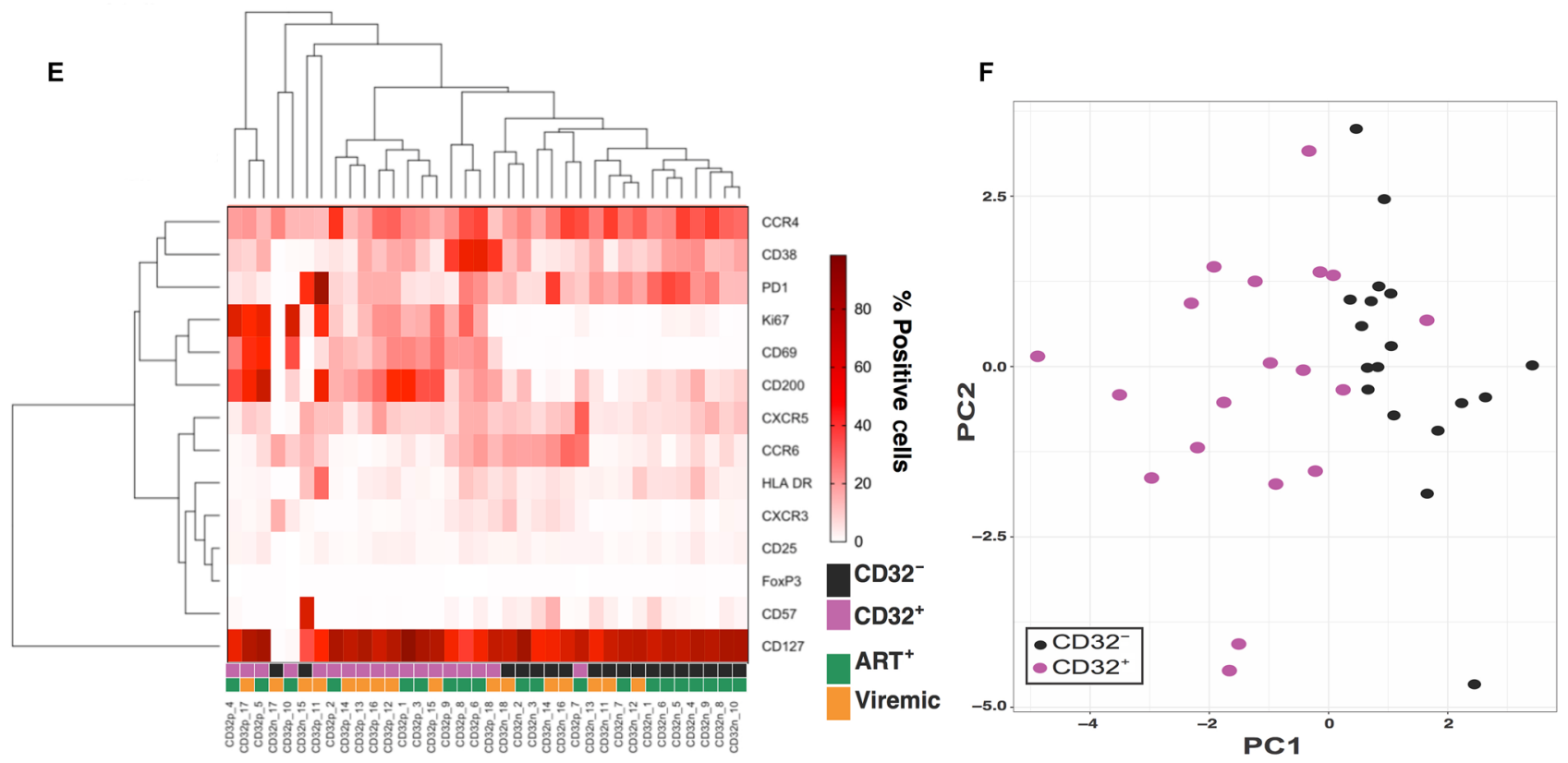

Fig. 2. CD32 ${ }^{+}$cells have a distinctively different phenotype compared to CD32- cells. (A) Distribution of CD32 ${ }^{+} H L A-D R^{-}$within cell subsets in viremic, $A R T-$ treated $H I V^{+}$ and $\mathrm{HIV}^{-}$donors. In the Barcelona cohort, subsets were defined as naïve $\left(\mathrm{CD} 45 \mathrm{RO}^{-} \mathrm{CD} 27^{+}\right), \mathrm{T}_{\mathrm{TD}}\left(\mathrm{CD}_{5} 5 \mathrm{RO}^{-} \mathrm{CD}^{-} 7^{-}\right)$, effector memory T cells $\left(\mathrm{T}_{\mathrm{EM}}\right)\left(\mathrm{CD} 45 \mathrm{RO}^{+} \mathrm{CD} 27^{-}\right)$, and central memory T cells $\left(\mathrm{T}_{\mathrm{CM}}\right)$ /transitional memory T cells $\left(\mathrm{T}_{\mathrm{TM}}\right)\left(\mathrm{CD} 45 \mathrm{RO}^{+} \mathrm{CD} 27^{+}\right)$. In the Philadelphia cohort, subsets were defined as naïve $\left(\mathrm{CD} 45 \mathrm{RA}{ }^{+} \mathrm{CD} 27^{+} \mathrm{CCR} 7^{+} \mathrm{CD} 95^{-}\right)$, stem memory

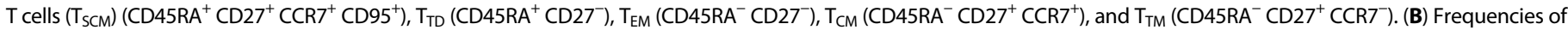
$\mathrm{T}_{\mathrm{H}}$ subsets within memory $\mathrm{CD} 32^{+} \mathrm{CD} 4^{+} \mathrm{T}$ cells (top) and their distribution within HLA-DR ${ }^{+-} \mathrm{TH}_{\mathrm{H}} 2 \mathrm{CD} 32^{+} \mathrm{CD} 4^{+} \mathrm{T}$ cells (bottom). Not subset refers to those cells that did not fall into the defined $\mathrm{T}_{\mathrm{H}}$ subsets. (C and D) Frequency of $\mathrm{CD} 38^{+}(\mathrm{C})$ and $\mathrm{Ki} 67^{+}(\mathrm{D})$ cells in $\mathrm{CD} 32 / \mathrm{HLA}$-DR-expressing memory $\mathrm{CD} 4^{+} \mathrm{T}$ cells. Representative examples are shown for each marker with overlaid plots showing $\mathrm{CD} 32^{+}$cells (red dots in plots and solid red lines in histograms) over total memory cells (black dots in plots and dotted lines in histograms). (E) Heat map showing the frequency of all measured phenotypic markers in CD32 ${ }^{+}$and CD32- cells. CD32p, memory CD $32^{+} \mathrm{CD} 4^{+} \mathrm{T}$ cells; CD32n, memory CD32- CD4 ${ }^{+} \mathrm{T}$ cells. (F) PCA showing the distribution of $\mathrm{CD} 32^{+}$and $\mathrm{CD} 32^{-}$cell subsets. In all graphs, a line indicates the median of the group. All data were analyzed using a Friedman test (paired, nonparametric) and corrected for multiple comparisons with Dunnett's posttest. $n=6$ for $\mathrm{HIV}^{-}$controls, $n=12 \mathrm{for} \mathrm{HIV}^{+} \mathrm{ART}^{+}$individuals, and $n=8$ for HIV ${ }^{+}$viremic individuals. ${ }^{*} P<0.05,{ }^{* *} P<0.01,{ }^{* *} P<0.001$, and ${ }^{* * *} P<0.0001$. 

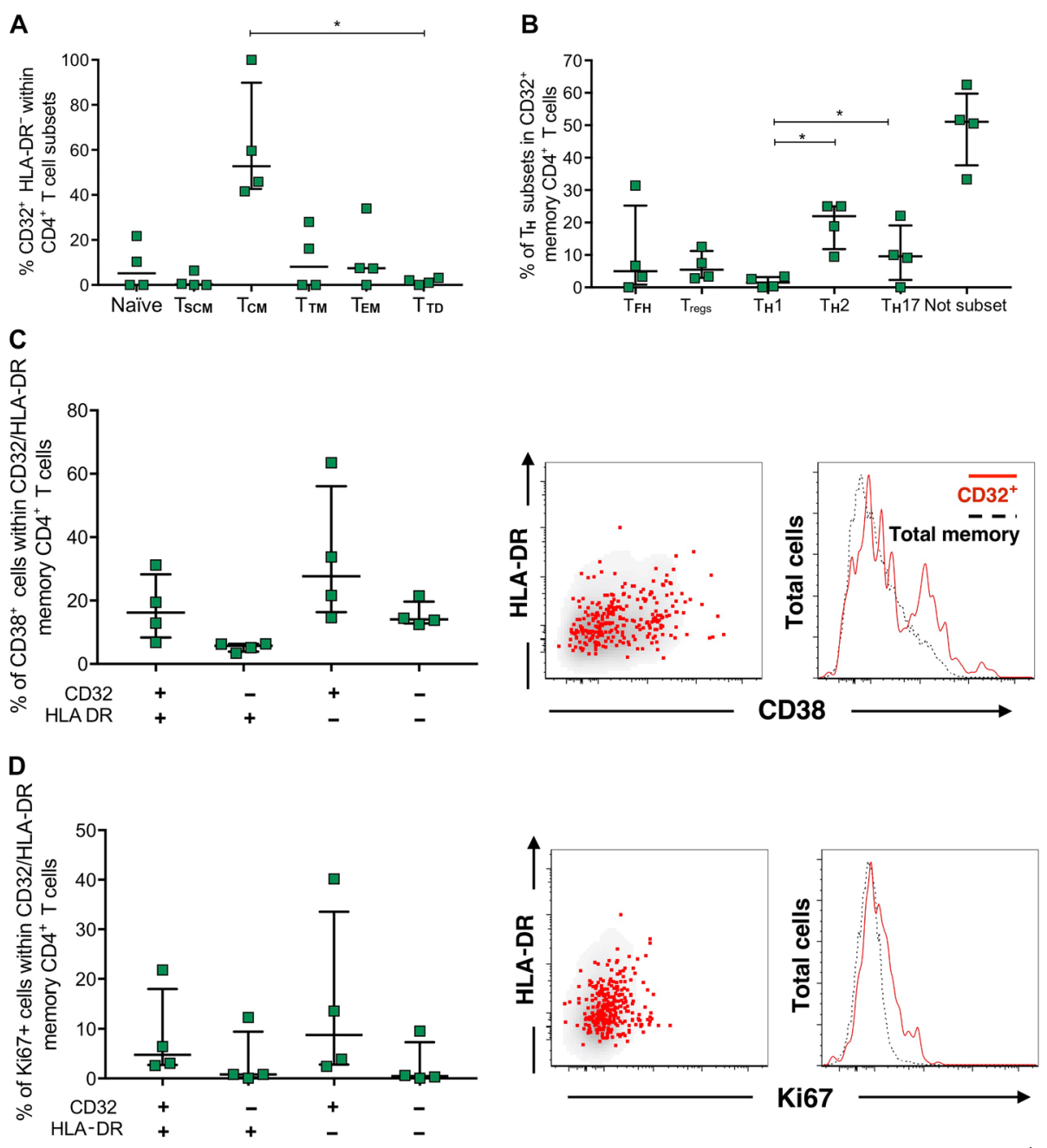

E

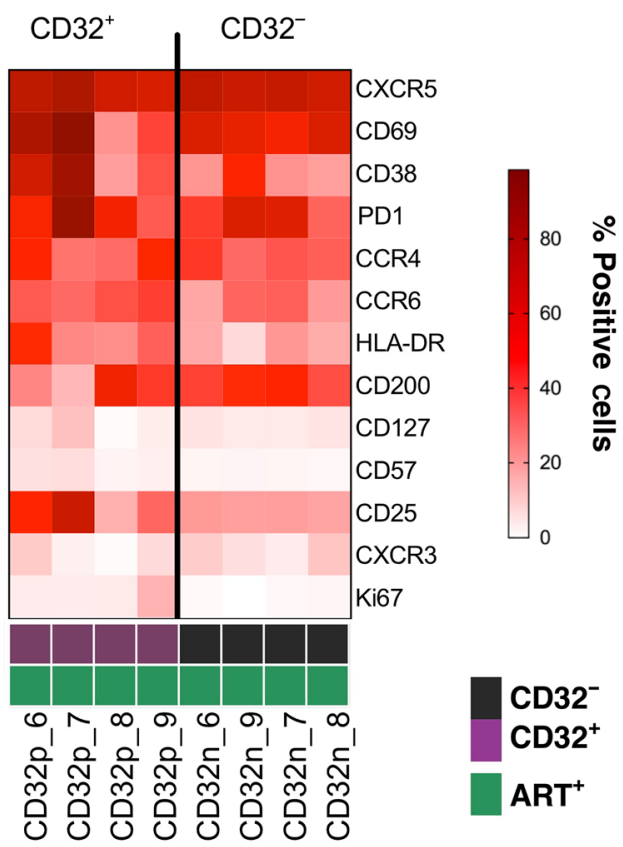

as cells coexpressing HIV RNA and the p24 viral protein (Fig. 4A). At day 3 after infection, we found that a median of $11 \%$ of infected cells expressed CD32 compared to uninfected cells, present in the same culture, in which fewer cells were expressing CD32 (median, $0.45 \%$; Fig. 4B). This percentage of CD32 was longitudinally stable on HIV-infected cells. Moreover, a direct positive correlation was found between the percentage of HIV-infected cells and the intensity of CD32 expression on these infected cells, possibly suggesting that a portion of actively transcribing HIV-infected cells express CD32 after cell infection (Fig. 4B, right). We next investigated the expression of HLA-DR and PD-1 on productively infected cells coexpressing CD32 (Fig. 4C). Infected cells had a higher proportion of HLA-DR ${ }^{+}$cells, and this frequency was higher in $\mathrm{CD} 32^{+}$cells when compared to CD $32^{-}$cells (mean, 85.5 and $51.6 \%$ for $\mathrm{CD}_{32}{ }^{+}$and CD $32^{-}$infected cells, respectively, at day 3 after infection). Similar results were obtained for PD-1 expression: We found a mean frequency of $27.6 \%$ PD- $1^{+}$ CD $32^{+}$cells versus $14.8 \%$ PD $-1^{+}$CD $32^{-}$infected cells after 3 days of infection (Fig. 4C). Of note, uninfected cells expressed very low frequencies of both HLA-DR and PD-1 (1.8 and 1.1\%, respectively). Given that $\mathrm{CD} 32$ expression has been shown to increase after in vitro polyclonal activation (36), we then focused on HIV infection of previously activated $\mathrm{CD} 4^{+} \mathrm{T}$ cells. We observed an increase of CD32 in uninfected $\mathrm{CD} 4^{+} \mathrm{T}$ cells after 72 -hour exposure to anti-CD3/CD28 antibodies compared to controls $(P=0.007 ; n=8)$. As with nonactivated cells, we also found that $\mathrm{HIV}_{\mathrm{NL4}-3}$ infection of activated cells further up-regulates the frequency of $\mathrm{CD}_{32}{ }^{+}$cells (Fig. 4D).

Using an ex vivo tissue model of HIV infection, cervical tissues from two $\mathrm{HIV}^{-}$ patients were infected with $\mathrm{HIV}_{\mathrm{Bal}}$ virus. Twelve days after infection, cells were analyzed by flow cytometry to characterize the frequency of infected cells and their coexpression of CD32 and HLA-DR. HIV-infected cells showed larger proportions of $\mathrm{CD} 32^{+}$cells than uninfected $\mathrm{CD}^{+}{ }^{+} \mathrm{T}$ cells (median, 18.2 and $5.9 \%$ for infected and uninfected cells, respectively) (Fig. 4E). Infected CD32 ${ }^{+}$cells also had higher frequencies of HLA-DR ${ }^{+}$cells compared to CD $32^{-} \mathrm{CD}^{+}{ }^{+} \mathrm{T}$ cells (median, 38.1 and $16.5 \%$ for infected $\mathrm{CD}_{2} 2^{+}$and $\mathrm{CD} 32^{-}$, respectively) (Fig. 4F). Overall, after ex vivo infection of unstimulated PBMCs and cervical tissue, $\sim 15 \%$ of infected cells expressed the CD32 marker, and this population had higher HLADR and PD-1 frequencies than their CD32counterparts. 


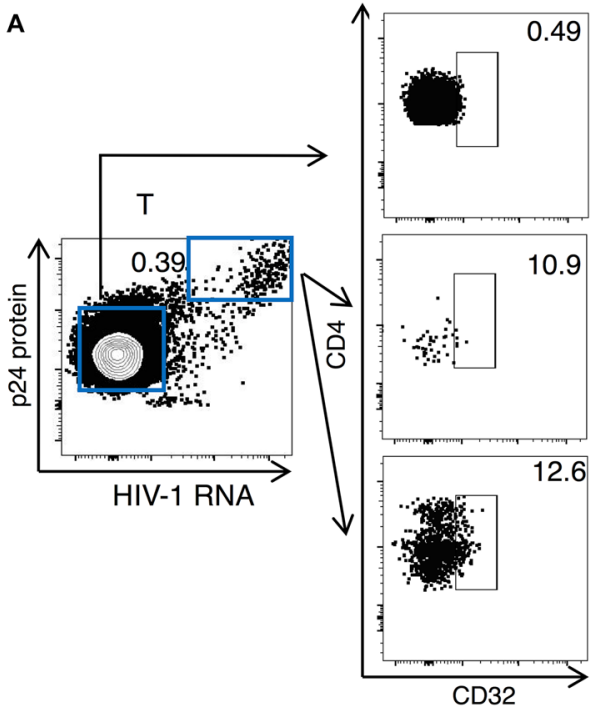

B
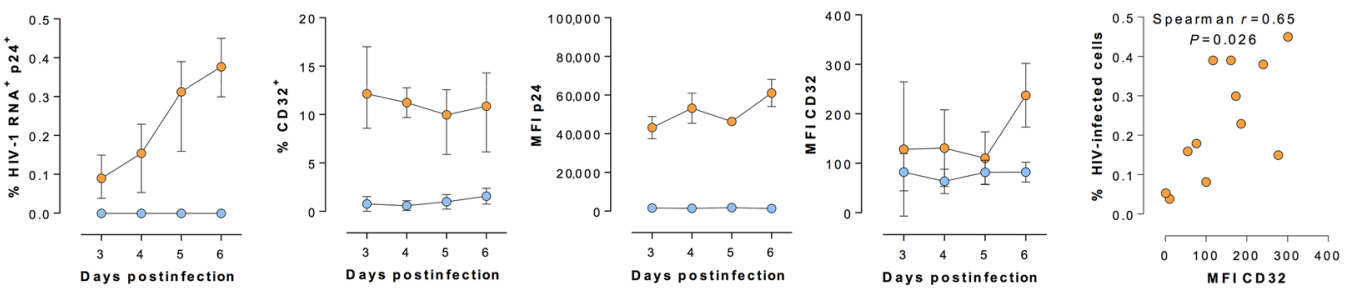

C
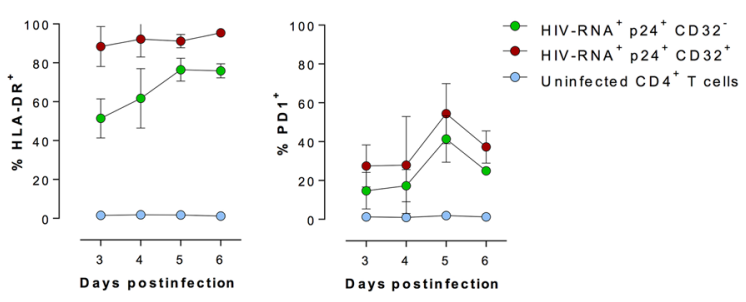

E

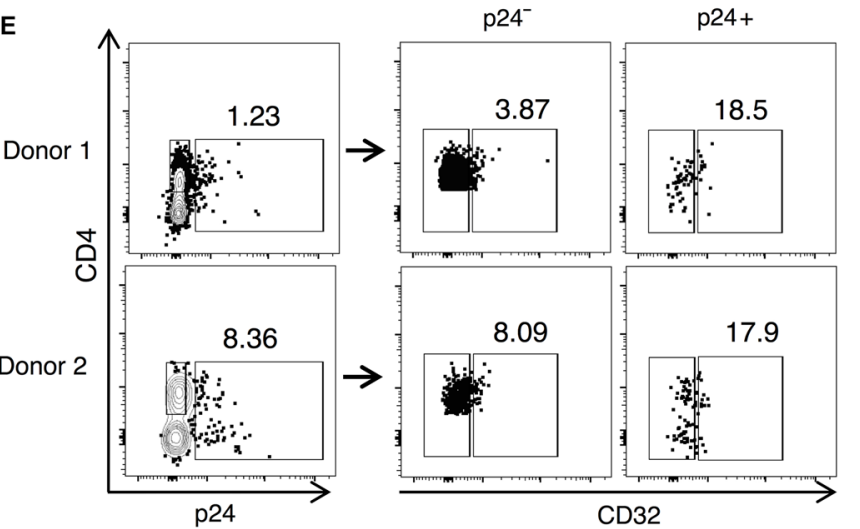

$\mathrm{CD}^{2}{ }^{+} \mathrm{CD}^{+}{ }^{\mathrm{T}}$ cells from ART-suppressed HIV-infected patients show no enrichment of HIV DNA, and CD32 ${ }^{+}$resting and activated $\mathrm{CD4}^{+} \mathrm{T}$ cells contribute minimally to the total pool of HIV DNA in CD4 ${ }^{+} \mathrm{T}$ cells

To investigate the possible role of CD32 expression for identifying the HIV reservoir in vivo, measurements of HIV DNA were per-
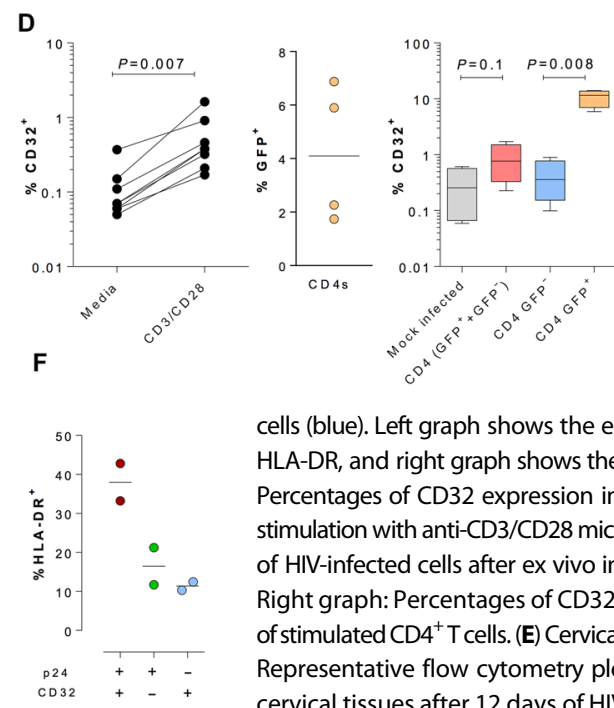
cells (blue). Left graph shows the expression of the activation marker HLA-DR, and right graph shows the expression of PD-1. (D) Left graph: Percentages of CD32 expression in uninfected cells after exogenous stimulation with anti-CD3/CD28 microbeads. Middle graph: Percentages of HIV-infected cells after ex vivo infection of stimulated $\mathrm{CD} 4^{+} \mathrm{T}$ cells. Right graph: Percentages of CD32 expression after ex vivo infection of stimulated $\mathrm{CD}^{+}{ }^{+} \mathrm{T}$ cells. (E) Cervical tissue ex vivo infection. Left graph: Representative flow cytometry plot of p24 protein detection in two cervical tissues after 12 days of HIV infection. Right graph: Detection of CD32 in HIV-infected cells and in uninfected CD4 ${ }^{+} \mathrm{T}$ cells. (F) Percentages of HLA-DR expression in infected cells expressing the CD32 marker (maroon), infected cells that do not express CD32 (green), and uninfected CD4 ${ }^{+} T$ cells expressing CD32 (blue). Statistical comparisons were performed using paired $t$ tests. $n=2$.

formed on CD32 pull-downs with anti-CD32 antibody-conjugated magnetic beads (with PBMCs from $\mathrm{HIV}^{+}$ART-suppressed individuals) and compared to preimmunoprecipitation pull-downs normalized for cell numbers. We did not detect any enrichment of HIV DNA in $\mathrm{CD}^{+}{ }^{+} \mathrm{CD} 32^{+}$pull-downs relative to controls (Fig. $5 \mathrm{~A}$ ). In addition, we used anti-CD32 antibody-conjugated magnetic beads 
Fig. 5. No enrichment of HIV DNA in sorted $\mathrm{CD}_{2}{ }^{+} \mathrm{CD}^{+} \mathrm{T}$ cells compared to $\mathrm{CD} 32^{-} \mathrm{CD}^{+}$ $T$ cells and $\mathrm{CD} 2^{+}$resting $\mathrm{CD4}^{+} \mathrm{T}$ cells contribute minimally to the total pool of HIV DNA in $\mathrm{CD}^{+}$ T cells. (A) Measurements of HIV DNA were performed on CD32 pull-downs with antibodyconjugated magnetic beads and compared to cell number normalized pre-immunoprecipitation (pre-IP) pull-downs $(n=7)$ on fresh cells. (B) HIV DNA load was measured from $\mathrm{CD}_{2} 2^{+}$resting $\mathrm{CD}^{+}$ T cells and $C D 32^{-}$resting $C D 4^{+} T$ cells isolated using magnetic beads $(n=6)$. (C) FACS was performed to isolate total $\mathrm{CD}^{+}{ }^{+} \mathrm{T}$ cells, $\mathrm{CD} 32^{+} \mathrm{CD} 4^{+} \mathrm{T}$ cells, $\mathrm{CD} 32^{-}$ $\mathrm{CD}^{+} \mathrm{T}$ cells, $\mathrm{CD} 32^{-}$resting $\mathrm{CD} 4^{+} \mathrm{T}$ cells (HLA-DR ${ }^{-}$ CD69 $\left.{ }^{-} \mathrm{CD} 25\right)$ ), CD32 ${ }^{+}$resting $\mathrm{CD} 4^{+} \mathrm{T}$ cells, CD32 ${ }^{-}$activated $\mathrm{CD}^{+}{ }^{+} \mathrm{T}$ cells $\left(\mathrm{HLA}-\mathrm{DR}{ }^{+}\right.$or $\mathrm{CD} 9^{+}$or $\left.\mathrm{CD} 25^{+}\right)$, and $\mathrm{CD}_{2}{ }^{+}$activated $\mathrm{CD} 4^{+} \mathrm{T}$ cells from freshly isolated PBMCs from $\mathrm{HIV}^{+}$ART-suppressed individuals, and HIV DNA load was measured in all sorted populations $(n=10)$. Each patient is represented by a different symbol. Lines represent median. (D and E) Contribution of each cell population to the total pool of HIV DNA in $\mathrm{CD}^{+}$T cells calculated in $10 \mathrm{HIV}^{+}$ART-suppressed individuals. HIV total DNA copy number was determined in sorted subsets by qPCR. Each symbol represents a different individual. The contribution of each subset to the total pool of HIV DNA in $\mathrm{CD}^{+} \mathrm{T}$ cells was calculated by accounting for the frequency of these subsets within the $\mathrm{CD}^{+}$compartment and abundance of HIV DNA determined in each subset. Horizontal lines indicate median values. All statistical comparisons were performed using two-tailed Wilcoxon rank tests. ${ }^{*} P<0.05$ and ${ }^{* *} P<0.01$.

to isolate $\mathrm{CD} 32^{+}$resting $\mathrm{CD} 4^{+} \mathrm{T}$ cells (HLA-DR ${ }^{-} \mathrm{CD}^{-} 9^{-} \mathrm{CD} 25^{-}$) and $\mathrm{CD} 32^{-}$ resting $\mathrm{CD}^{+} \mathrm{T}$ cells from PBMCs of $\mathrm{HIV}^{+}$ART-suppressed individuals. No enrichment of HIV DNA was observed in $\mathrm{CD} 32^{+}$resting $\mathrm{CD} 4^{+} \mathrm{T}$ cells when compared to $\mathrm{CD} 32^{-}$resting $\mathrm{CD} 4^{+} \mathrm{T}$ cells (Fig. 5B). Finally, we measured HIV DNA in $\mathrm{CD} 4^{+} \mathrm{T}$ cells FACS (fluorescenceactivated cell sorting)-sorted based on activation status and CD32 expression as shown in Fig. 5C. All sorted populations were isolated within 2 hours of collection of blood from $\mathrm{HIV}^{+}$ARTsuppressed individuals (Fig. 5C and table S2). No enrichment of HIV DNA load was observed between all compared populations. In addition, the contribution of $\mathrm{CD} 32^{+} \mathrm{CD} 4^{+} \mathrm{T}$ cells to the total pool of HIV DNA in $\mathrm{CD}^{+} \mathrm{T}$ cells was significantly lower than that of $\mathrm{CD} 32^{-} \mathrm{CD} 4^{+} \mathrm{T}$ cells (Fig. 5, D and E). Our data show that $\mathrm{CD} 32^{-}$resting $\mathrm{CD} 4^{+} \mathrm{T}$ cells contribute the most (median, $75.86 \%$ ) to the total pool of HIV DNA in total CD4 ${ }^{+}$ $\mathrm{T}$ cells, followed by $\mathrm{CD} 32^{-}$activated $\mathrm{CD} 4^{+} \mathrm{T}$ cells (median, $18.1 \%$ ),

A

C

D
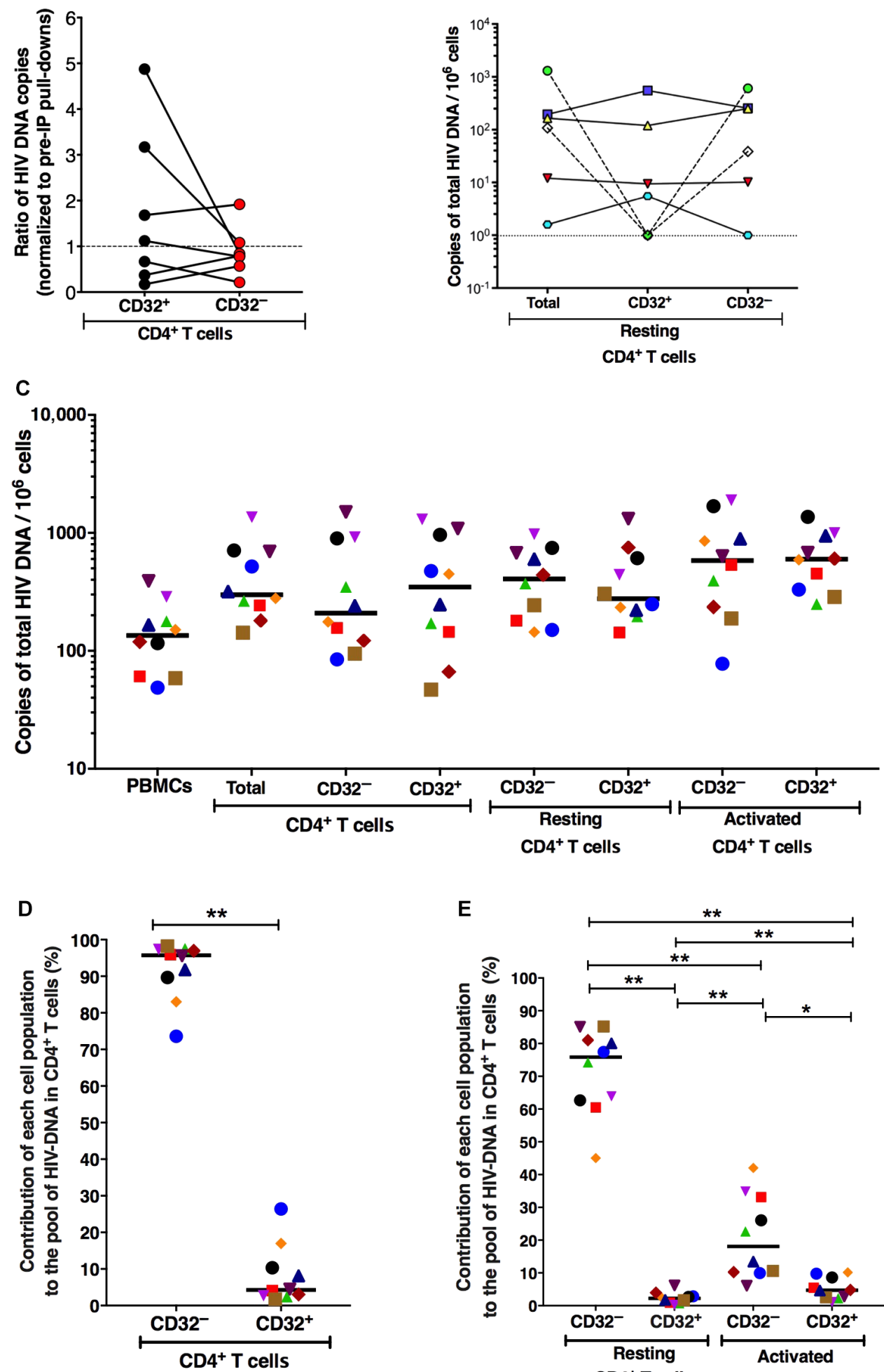

B

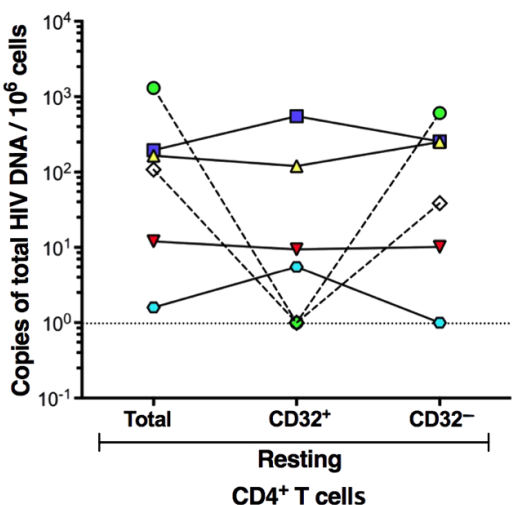

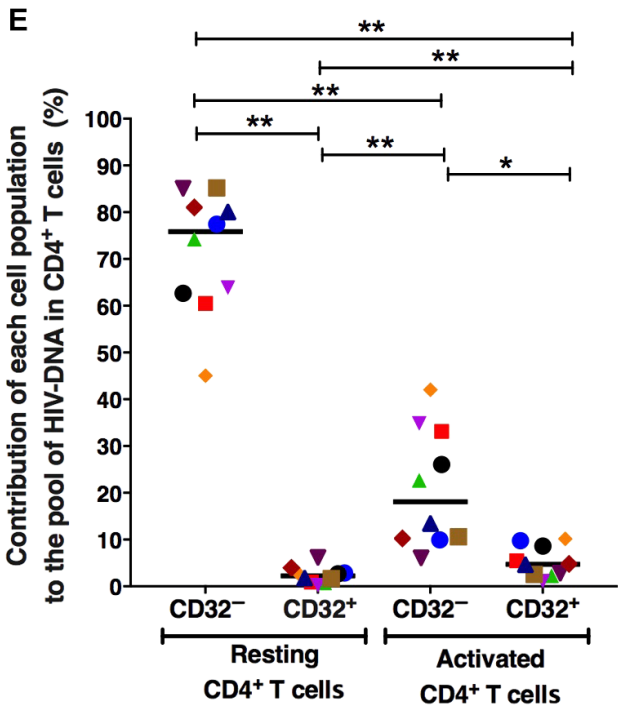

$\mathrm{CD} 32^{+}$activated $\mathrm{CD} 4^{+} \mathrm{T}$ cells (median, $4.7 \%$ ), and, last, $\mathrm{CD} 32^{+}$ resting $\mathrm{CD} 4^{+} \mathrm{T}$ cells (median, $2.2 \%$ ). Similar analyses were performed on $\mathrm{CD}_{2} 2^{+}$versus $\mathrm{CD} 32^{-} \mathrm{CD} 4^{+} \mathrm{T}$ cells isolated from the LNs of the five ART-suppressed SIV-infected RMs described above. No 
enrichment of SIV DNA was detected in $\mathrm{CD} 32^{+} \mathrm{CD} 4^{+} \mathrm{T}$ cells when compared to $\mathrm{CD} 32^{-} \mathrm{CD} 4^{+} \mathrm{T}$ cells in the LNs of ART-suppressed, SIV-infected RMs (fig. S5).

\section{$\mathrm{CD} 32$ on $\mathrm{CD}^{+} 9^{+}$but not on resting $\mathrm{CD}^{+}{ }^{+}$cells enriches for HIV DNA and RNA in peripheral blood from ART-suppressed HIV-infected patients}

The frequency of $\mathrm{CD}_{2} 2^{+}$cells on total or resting $\mathrm{CD} 4^{+} \mathrm{T}$ cells was not associated with total HIV DNA load measured by quantitative polymerase chain reaction (qPCR) [Fig. 6 (A and B) and fig. S6 (A to D)]; however, the frequency of $\mathrm{CD} 32^{+} \mathrm{CD} 69^{+} \mathrm{CD} 4^{+} \mathrm{T}$ cells exhibited a moderate significant correlation with total HIV DNA load in isolated $\mathrm{CD}^{+} \mathrm{T}$ cells from $\mathrm{HIV}^{+}$ART-suppressed individuals (rho $=0.44, P=0.036$ ) (Fig. 6, C and D). Because CD32 ${ }^{+}$cells are enriched in activated cells that are likely transcriptionally active, we sought to examine a possible correlation between CD32 expression and cell-associated HIV RNA load as a marker of HIV transcription in PBMC from $\mathrm{HIV}^{+}$ART-suppressed individuals. Cell-associated HIV RNA load correlated positively with the frequency of CD32 $2^{+}$ $\mathrm{CD} 9^{+} \mathrm{CD} 4^{+} \mathrm{T}$ cells as measured in PBMCs ( $\mathrm{rho}=0.48, P=0.0099$ ) or in isolated $\mathrm{CD} 4^{+} \mathrm{T}$ cells ( $\mathrm{rho}=0.66, P=0.0002$ ), but not with frequencies of $\mathrm{CD}_{2} 2^{+}$on total $\mathrm{CD} 4^{+} \mathrm{T}$ cells (Fig. 6, E to H), or resting $\mathrm{CD}^{+} \mathrm{T}$ cells (fig. S6, E and F). Whereas CD32 and CD69 expression showed the highest association with cell-associated HIV RNA load, CD69 expression in $\mathrm{CD}^{-} 2^{-} \mathrm{CD}^{+} \mathrm{T}$ cells also showed a lower but significant correlation with cell-associated HIV RNA load measured in unfractionated PBMCs $(\mathrm{rho}=0.4, P=0.04)$ and isolated $\mathrm{CD}^{+}$ T cells ( $r h o=0.53, P=0.004$ ) (fig. S7), indicating that not all circulating $\mathrm{CD}^{+} \mathrm{T}$ cells that are HIV transcriptionally active express CD32. However, as shown in fig. S6 ( $\mathrm{K}$ to $\mathrm{R})$, total activated $\left(\mathrm{CD} 9^{+}\right.$or $\mathrm{HLDR}^{+}$or $\mathrm{CD}_{2} 5^{+}$) $\mathrm{CD}_{2} 2^{-}$or resting $\mathrm{CD} 4^{+} \mathrm{T}$ cells did not show significant associations with cell-associated HIV RNA load.

\section{CD32 expression associates with HIV-RNA in LNs of HIV-infected patients}

To better understand the relationship between HIV RNA and CD32a expression, we visualized and quantified HIV RNA and CD32a RNA in anatomically intact LN tissue from viremic and ART-treated $\mathrm{HIV}$-infected patients, and $\mathrm{HIV}^{-}$controls. HIV RNA and CD32a RNA were detected in paraffin-embedded tissue samples. As shown in Fig. 7A, we observed two HIV RNA expression patterns: (i) productively HIV-infected cells that typically have a densely staining spherical signal that involves the entire cell and (ii) small punctate structures with a diffuse lattice-like signal pattern compatible with the capture of HIV virions by follicular dendritic cells in B cell follicles, as reported previously (37). Of note, we did not perform the phenotypic identification of transcriptionally active infected cells in LNs, but reports have shown that productively HIV-infected cells align with $\mathrm{CD} 45 \mathrm{RO}^{+}$memory $\mathrm{CD} 4^{+} \mathrm{T}$ cells (38). Using a specific set of RNA probes, we evaluated CD32a expression. The observed staining and localization of CD32a were compatible with the presence of subcapsular sinus macrophages in LNs. In addition, in the analyzed six HIV-infected patients, a high percentage of HIV-expressing cells localized within the B cell follicle also coexpressed the CD32a transcripts (median, $94 \%$ ) compared to $4 \%$ of cells that were single CD32 ${ }^{+}$ and $2 \%$ of cells that only expressed HIV RNA. The B cell follicle has been identified as an immune-privileged sanctuary site for HIV persistence (39). No differences were observed between viremic and aviremic donors (Fig. 7B). After inspecting a median of $74 \mathrm{~B}$ cell follicles per donor, CD32a single-positive cells were detected at a median frequency of $6.3 \%$ in viremic and $1.7 \%$ in ART-treated patients. Cells coexpressing the CD32a receptor and HIV RNA were detected at a median frequency of $94.3 \%$ in viremic and $60.2 \%$ in ART-treated patients (Fig. 7C and fig. S8). Of note, CD32a was highly up-regulated in HIV RNA-positive HIV-infected cells. The
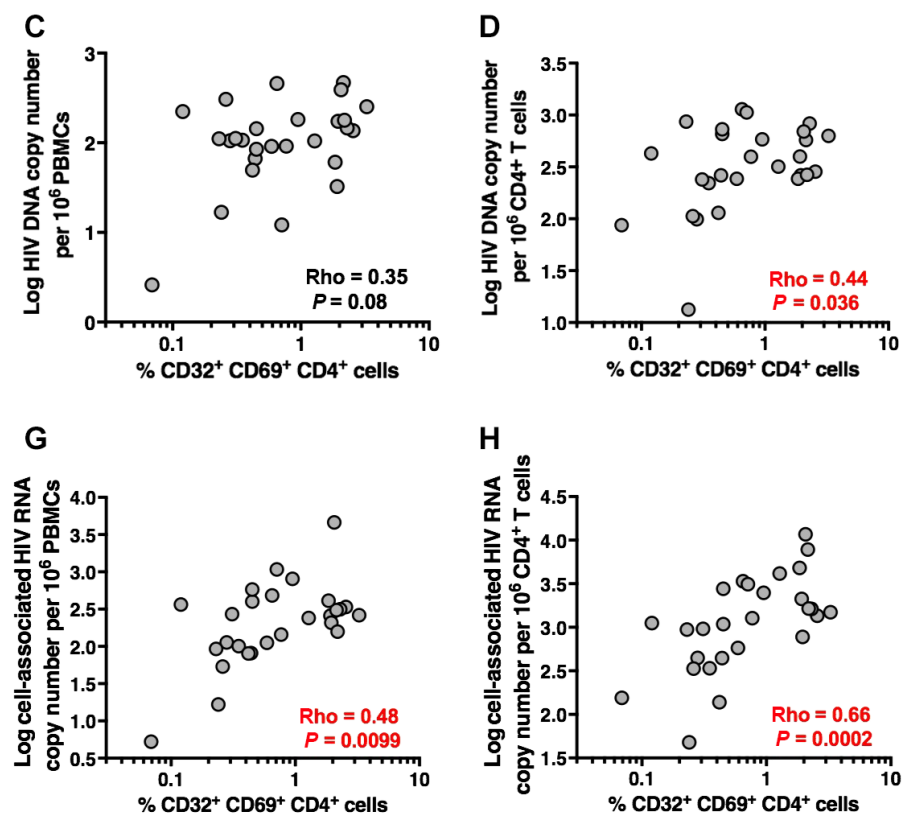
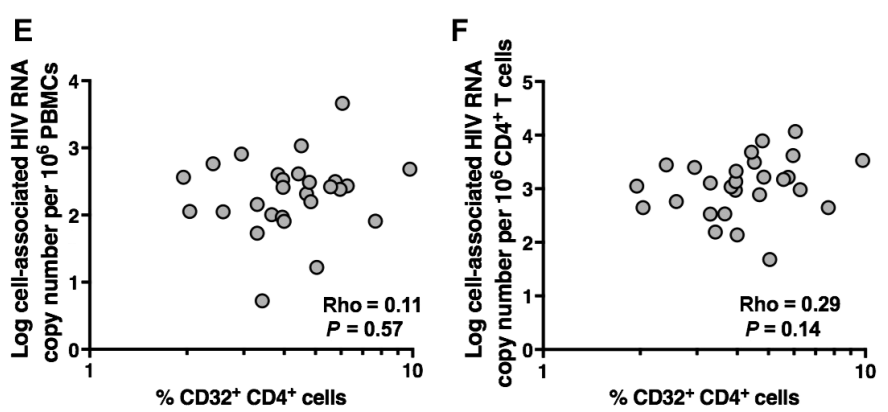

Fig. 6. Frequency of $\mathrm{CD}_{32}{ }^{+}$on $\mathrm{CD}^{+} 9^{+}$cells correlates with HIV DNA and RNA loads during suppressive ART. (A to D) Frequency of $\mathrm{CD} 32^{+} \mathrm{CD} 4^{+} \mathrm{T}$ cells and frequency of $\mathrm{CD}_{2} 2^{+}$on $\mathrm{CD} 9^{+} \mathrm{CD} 4^{+} \mathrm{T}$ cells were examined in relation to total HIV DNA load measured in unfractionated PBMCs and isolated $\mathrm{CD} 4^{+} \mathrm{T}$ cells. $(\mathbf{E}$ to $\mathrm{H})$ Frequency of $\mathrm{CD} 32^{+}$ $\mathrm{CD}^{+} \mathrm{T}$ cells and frequency of $\mathrm{CD} 32^{+}$on $\mathrm{CD}_{6} 9^{+} \mathrm{CD}^{+} \mathrm{T}$ cells were examined in relation to cell-associated HIV RNA load measured in unfractionated PBMCs and isolated $\mathrm{CD}^{+}{ }^{+} \mathrm{T}$ cells. Correlations were evaluated using two-tailed Spearman's rank correlation coefficient tests. $n=27 \mathrm{HIV}^{+} \mathrm{ART}^{+}$individuals. 

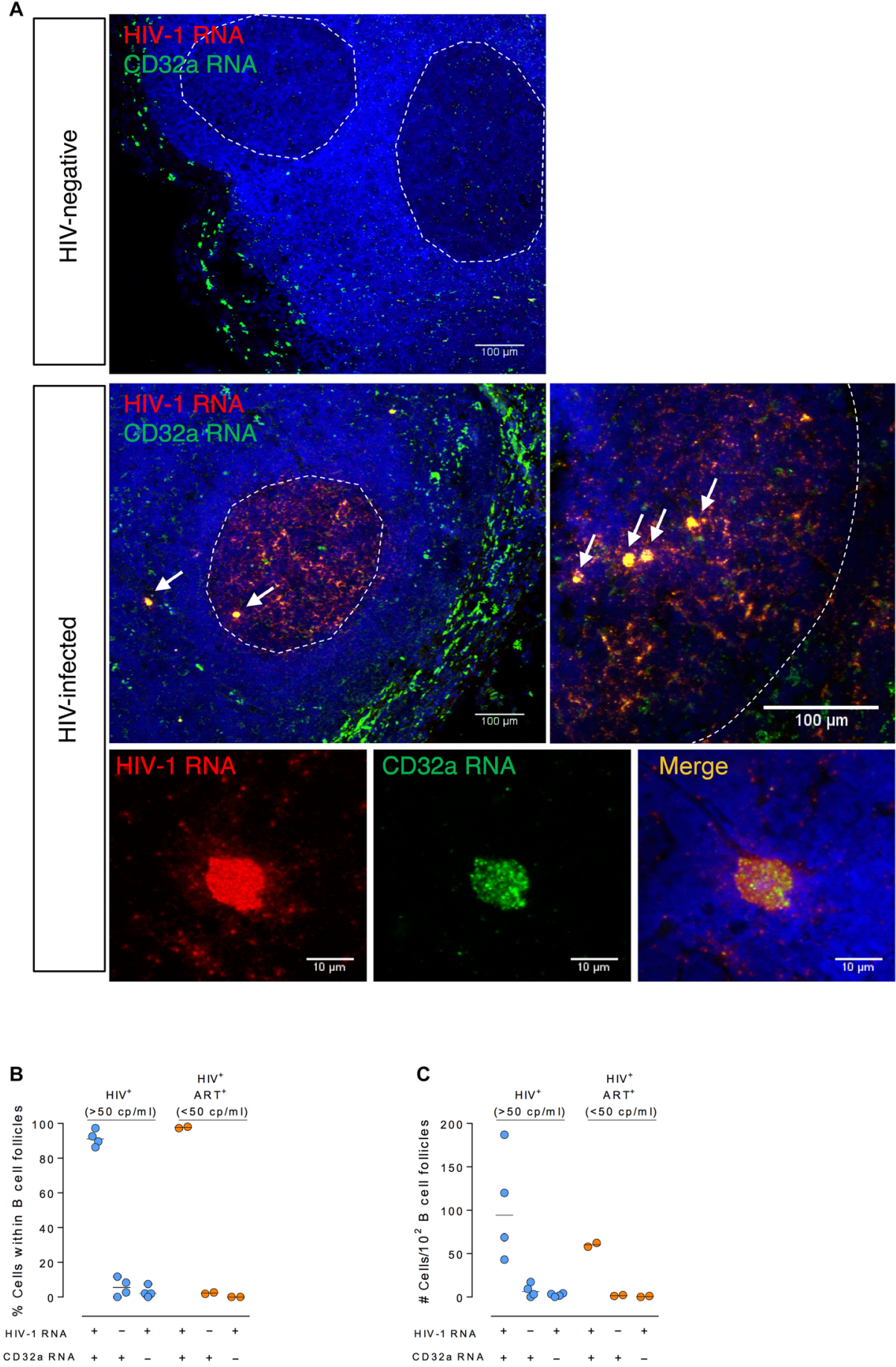

D

Patient 1

Patient 2

Patient 3
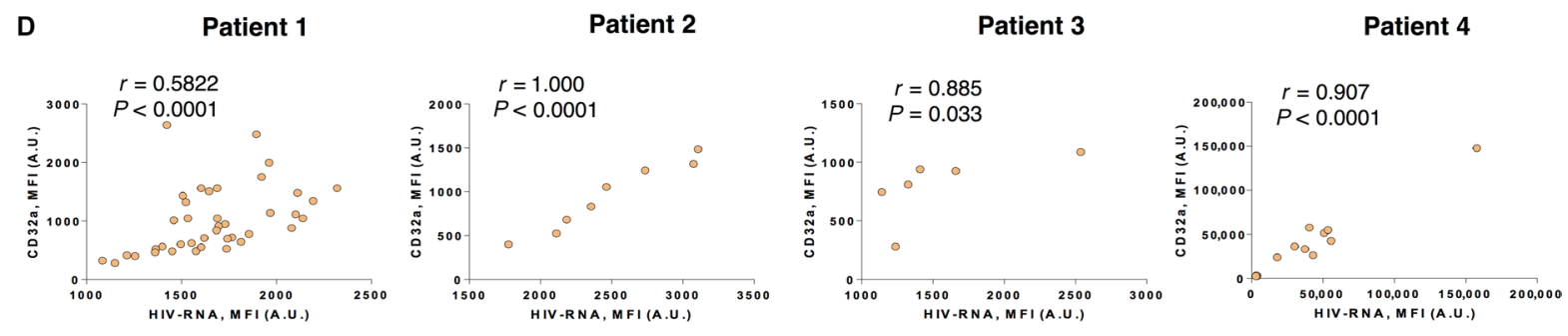

Fig. 7. CD32 expression associates with HIV-RNA.

(A) Paraffin-embedded sections from HIV-infected patients and a healthy donor LN biopsy were stained for HIV-1 RNA (red), CD32a RNA (green), and nuclei (blue). Upper panel shows a representative section of an $\mathrm{HIV}^{-}$donor, and a viremic HIV-infected patient is shown in lower panels. White arrows indicate cells coexpressing HIV and CD32a. Lower panels show high magnification of one cell coexpressing HIV and CD32a from a viremic HIV-infected patient. (B and C) Quantification of single HIV-1 RNA-, single CD32a RNA-, and double HIV-1 RNA- and CD32a RNA-positive cells in $B$ cell follicles of $L N s$ from four HIV-infected viremic patients, and two HIV-infected patients with undetectable viral load. Results are represented (B) as a percentage of the total HIV RNApositive cells and/or CD32a RNA-positive cells within $B$ cell follicles or (C) as the total number of cells per $10^{2}$ inspected $B$ cells follicles. (D) Spearman correlation between the MFI of CD32 RNA expression and the MFI of HIV-1 RNA expression. The same four viremic HIV-positive patients used in (B) and (C) are shown. $n=6$. A.U., arbitrary units. 
expression for both RNAs, HIV and CD32a [defined by the mean fluorescence intensity (MFI)], was highly correlated in all analyzed patients (Fig. 7D). Overall, in LNs of HIV-infected patients, most of the cells expressing HIV RNA also coexpress the CD32a receptor, whereas CD32a single-positive cells within the B cell follicle were rarely observed.

\section{DISCUSSION}

We report that CD32 expression in $\mathrm{CD}^{+} \mathrm{T}$ cells is a marker for a subset of activated $\mathrm{CD}^{+}{ }^{+} \mathrm{T}$ cells containing HIV transcripts after ART-mediated suppression. We find no evidence to support that CD32 expression favors resting $\mathrm{CD}^{+}{ }^{+} \mathrm{T}$ cells or enriches for $\mathrm{HIV}$ DNA copy number in sorted resting $\mathrm{CD}^{+} \mathrm{T}$ cells commonly used to measure the latent HIV reservoir. We found evidence that CD32 expression favors activated $\mathrm{CD} 4{ }^{+} \mathrm{T}$ cells and is coexpressed with HIV RNA in infected cells in vitro and in vivo.

Our data showing no enrichment of HIV DNA in CD $32^{+} \mathrm{CD} 4^{+}$ cells do not confirm the data in the recent report by Descours et al. (24) that $\mathrm{CD} 32^{+} \mathrm{CD}^{+} \mathrm{T}$ cells contribute 26.8 to $83.3 \%$ to the total pool of HIV DNA in $\mathrm{CD}^{+}{ }^{+} \mathrm{T}$ cells. Our data show that $\mathrm{CD} 32^{-}$resting $\mathrm{CD} 4^{+}$ $\mathrm{T}$ cells contribute the most to the total pool of HIV DNA in total $\mathrm{CD} 4^{+} \mathrm{T}$ cells $(\sim 76 \%)$, whereas $\mathrm{CD} 32^{+} \mathrm{CD} 4^{+} \mathrm{T}$ cells, activated or resting, contribute minimally to this pool (4.7 and $2.2 \%$, respectively). These results challenge the notion that CD32 enriches for HIV latently infected cells as suggested by Descours et al. (24). The reasons for this discrepancy remain unclear.

Although the expression of low-affinity Fc receptors, including $\mathrm{CD} 32$, on $\mathrm{CD} 4^{+} \mathrm{T}$ cells remains controversial $(25,26)$, resting $\mathrm{CD} 4^{+}$ $\mathrm{T}$ cells express low frequencies of CD32, whereas CD32 expression increases upon T cell activation $(27-29,40)$. We found that expression of CD32 is enriched within cells expressing markers routinely used to deplete activated cells when studying HIV latency (CD69, HLA-DR, and CD25) (7, 30-35). Activation levels of the donor samples used in the report by Descours et al. were not reported. Therefore, it remains unclear whether the lower viral outgrowth from $\mathrm{CD} 32$-depleted $\mathrm{CD} 4^{+} \mathrm{T}$ cells reported by Descours et al. reflects outcomes associated with large disparities in baseline $\mathrm{T}$ cell activation between donors.

Immunoprofiling of $\mathrm{CD}_{2} 2^{+} \mathrm{CD} 4^{+} \mathrm{T}$ cells in blood and tissues of humans and RMs shows that these cells exhibit an activated and differentiated phenotype, making it unlikely that they are enriched with HIV latently infected cells. We were also unable to detect differences in the frequencies of $\mathrm{CD}_{2} 2^{+} \mathrm{CD} 4^{+} \mathrm{T}$ cells between HIVinfected individuals (viremic and ART-suppressed) and healthy donors, otherwise expected if CD32a was a preferential biomarker for $\mathrm{HIV}-1$ infection in $\mathrm{CD} 4^{+} \mathrm{T}$ cells (irrespective of latent or active infection). It was of interest to detect enrichment of markers consistent with $\mathrm{T}_{\mathrm{H}} 2$ cells (blood and tissue) and $\mathrm{T}_{\mathrm{H}} 17$ cells (tissue) within $\mathrm{CD} 32^{+} \mathrm{CD}^{+} \mathrm{T}$ cells. These phenotypes have been associated with HIV persistence and enriched replication capacity in vitro and ex vivo (41-45). It is important to consider, however, that the enrichment within the $\mathrm{T}_{\mathrm{H}} 17$ observed in tonsils, but not in peripheral blood, may be due solely to the rarity of this subset in circulation compared to lymphoid tissue.

Our in vitro analyses show a direct link between CD $32^{+}$expression and productive HIV infection. Although HIV-infected CD $32^{+}$ $\mathrm{CD} 4^{+} \mathrm{T}$ cells are more activated than HIV-infected CD $32^{-} \mathrm{CD} 4^{+}$ T cells, not all infected cells expressing HIV proteins were CD32 ${ }^{+}$.
Our data do not exclude the possibility that $\mathrm{CD}_{2}{ }^{+}$cells are also preferentially infected. This possibility is very likely because CD $32^{+}$ cells are more activated. However, these possibilities separately or jointly would not significantly affect our conclusion that a portion of cells actively transcribing HIV are also expressing CD32.

Consistent with the notion that $\mathrm{CD} 32^{+} \mathrm{CD} 4^{+} \mathrm{T}$ cells are enriched with transcriptionally active infection, cell-associated HIV RNA load was mostly closely associated with the activation and the expression of CD32 on $\mathrm{CD} 9^{+}$cells in both total and resting $\mathrm{CD} 4{ }^{+}$ $T$ cells in the periphery. In addition, our RNA FISH experiments showing the coexpression of CD32a and HIV RNA in lymph tissue directly support the interpretation that CD32a is more likely to be associated with transcriptionally active rather than latent infection.

The role of CD32, if any, in determining the enrichment of HIV expression remains unknown. Fc $\gamma$ RII receptors play critical roles in shaping different immunological outcomes and direct antibody functionality (46). FcyRIIa and Fc $\gamma$ RIIc are activating receptors, whereas FcyRIIb is an inhibitory receptor (46). It remains unclear which functions are mediated by the immunomodulatory CD32 receptors on $\mathrm{CD} 4{ }^{+} \mathrm{T}$ cells with regard to HIV infection, expression, and immune evasion, especially if their expression is triggered by $\mathrm{T}$ cell receptormediated $\mathrm{T}$ cell activation.

The similarity of the extracellular domains of CD32a (FcyRIIa), CD32b (FcyRIIb), and CD32c (Fc $\gamma$ RIIc) does not allow us to differentiate between the three receptors by flow cytometry because there are no available antibodies that can distinguish among them, and the available CD32a-specific antibody showed very low resolution (47). However, our RNA FISH data in LNs were generated using a CD32a-specific probe. Our data were primarily obtained from blood, LN tissues, and tonsils; thus, the need to analyze the role of CD32a expression to HIV persistence in additional tissues (such as gutassociated lymphoid tissues) after ART remains. The concordance of our data with SIV-infected macaques showing a relationship between CD32 and activation and the lack of enrichment of SIV DNA in sorted $\mathrm{CD} 32^{+} \mathrm{CD} 4^{+} \mathrm{T}$ cells raise the possibility that the RM model may be useful in greater tissue-centered analysis, as well as in testing strategies aimed at directly targeting $\mathrm{CD} 32^{+} \mathrm{T}$ cells. Last, our data describe cross-sectional groups in chronically infected adults, thereby the need to also analyze longitudinal changes, acute infection, and pediatric cohorts not addressed by our report.

In summary, our results show that $\mathrm{CD} 32^{+} \mathrm{CD} 4^{+} \mathrm{T}$ cells exhibit a distinct activation profile for transcriptionally active HIV. Although CD32 may provide a novel tool to better understand persistent HIV expression after ART, our data also stress the remaining need to find reliable and specific HIV latency biomarkers in resting $\mathrm{CD} 4{ }^{+} \mathrm{T}$ cells for the development of effective targeting methods toward HIV eradication.

\section{MATERIALS AND METHODS Study design}

This study was performed on fresh and frozen PBMCs, and tonsils from $\mathrm{HIV}^{-}, \mathrm{HIV}^{+}$-treated, and $\mathrm{HIV}^{+}$viremic individuals (a total of 76 study participants; tables S1 and S3). PBMCs from HIV-infected viremic and ART-treated individuals were obtained from Wistar, The Centre for Research in Infectious Diseases (CIENI) of the National Institute of Respiratory Diseases (INER), and the Vall d'Hebrón Hospital. Tonsil samples were obtained from INER-CIENI. Healthy $\mathrm{HIV}^{-} \mathrm{PBMC}$ samples were obtained from Wistar and the University of 
Pennsylvania Human Immunology Core. Additional PBMCs from HIV-infected donors were obtained from the University of Toronto. Written informed consent was provided by all patients, and the protocols used were approved by the Comité d'Ëtica d'Investigació Clínica [Institutional Review Board (IRB) numbers 270/2015 and 196/2015], the INER-CIENI Ethics Committee, the Federal Commission for the Protection against Sanitary Risk (COFEPRIS; IRB number B03-16), and the IRBs of the University of Pennsylvania and Wistar (\#2110176). Primary data are shown in table S4.

\section{Animal studies}

Five male RMs (Macaca mulatta), housed at the Yerkes National Primate Research Center (Atlanta, GA), were included in this study. All procedures are approved by the Emory University Institutional Animal Care and Use Committee, and animal care facilities are accredited by the U.S. Department of Agriculture and the Association for Assessment and Accreditation of Laboratory Animal Care International.

\section{Ex vivo infection kinetics of unstimulated PBMCs}

PBMC samples from three healthy donors were used for these experiments. Briefly, frozen PBMCs were thawed and incubated overnight in R10 supplemented with streptomycin $(100 \mu \mathrm{g} / \mathrm{ml})$, penicillin $(100 \mathrm{U} / \mathrm{ml})$, and interleukin-2 (IL-2; $40 \mathrm{U} / \mathrm{ml})$. On the next day, one million PBMCs were infected with $350,000 \mathrm{TCID}_{50}$ (50\% tissue culture infectious dose) of NL4-3 viral strain for 4 hours at $37^{\circ} \mathrm{C}$ and $5 \% \mathrm{CO}_{2}$. After the initial infection, the cells were thoroughly washed and cultured in 96-well plates in R10 plus IL-2 (100 U/ml) for an additional 6 days to expand the initial viral infection. To focus our analysis on transcriptionally active HIV-infected cells, we performed the RNA FISH-flow assay at days 3, 4, 5, and 6, as previously described (48). For HIV RNA detection, we used target-specific Alexa Fluor 647-labeled probes that contain a set of 50 probes spanning the whole Gag-Pol HIV mRNA sequence (bases 1165 to 4402; reference HXB2). We include antibodies for surface markers CD4 (BV510; BioLegend), CD3 [phycoerythrin (PE)-Cy5; BioLegend], CD32 (PE-Cy7; BioLegend), HLA-DR (Pe-Dazzle 594; BioLegend), and PD-1 (BV605; BD). The intracellular expression of the viral Gag p24 viral protein was detected with a PE-anti-p24 antibody (clone KC57 RD1; Beckman Coulter). A violet viability dye for flow cytometry (LIVE/DEAD Fixable Violet Dead Cell Stain Kit, Invitrogen) was included in all experiments to determine the cell viability. All samples were run on an LSRFortessa fourlaser flow cytometer (Becton Dickinson) and analyzed with FlowJo v10 software (Tree Star).

\section{CD32 expression after in vitro infection of activated $\mathrm{CD4}^{+} \mathrm{T}$ cells}

PBMCs were isolated from peripheral blood obtained via phlebotomy from HIV-1-negative donors per an active, approved University of Utah IRB protocol (\#67637; principal investigator, A. M. Spivak). Total CD $4^{+} \mathrm{T}$ cells were purified via negative magnetic bead selection using a total $\mathrm{CD} 4^{+} \mathrm{T}$ cell-negative isolation kit (STEMCELL) according to the manufacturer's instructions. $\mathrm{CD} 4^{+} \mathrm{T}$ cells were cultured in an RPMI 1640-based media supplemented with IL-2 $(30 \mathrm{IU} / \mathrm{ml})$ and activated in vitro for 72 hours via exposure to antibodies to CD3 and CD28 conjugated to magnetic beads (Invitrogen). Activated $\mathrm{CD} 4^{+} \mathrm{T}$ cells subsequently underwent spin infection with an HIV-1 $1_{\mathrm{NL} 4-3}$ viral strain pseudotyped with green fluorescent protein in place of env (multiplicity of infection of about 1.0 using a titer measured in SupT1 cells) at $1200 \mathrm{~g}$ for 2 hours at $37^{\circ} \mathrm{C}$. CD $4^{+} \mathrm{T}$ cells were stained with the following fluorophore-conjugated antibodies before flow cytometry acquisition: CD3 (PE-Cy7; BioLegend), CD4 (allophycocyanin; Life Technologies), CD32 (PE; Fun-2 clone; BioLegend), CD14 [Brilliant Violet (BV) 421; BioLegend], and HLA-DR (BV 605; BD Biosciences). Flow cytometry was performed at $0,24,48$, and 72 hours relative to $\mathrm{CD}^{+} \mathrm{T}$ cell isolation, as well as 0,24 , and 48 hours after NL4-3 infection. Flow cytometry acquisition was performed on a BD FACSCanto II instrument, and analysis was performed using FlowJo v10 software.

\section{Ex vivo infection of cervical tissue}

Human cervical tissue was obtained from healthy women undergoing hysterectomy for benign indication at University Hospital Germans Trias i Pujol (HUGTP; Badalona, Spain). Informed written consent was obtained from all participants, and the study protocols (IRB protocol number PI-17-159) and questionnaires were approved by the HUGTP Clinical Research Ethics Committee. Tissue was processed within 12 hours after surgery, and $8-\mathrm{mm}^{3}$ blocks of mucosal epithelium with the underlying stroma were dissected as previously described (49). Eight blocks of tissue per condition were placed in RPMI 1640 supplemented with $20 \%$ fetal bovine serum (R20) in a 12 -well plate and infected with 7200 TCID $_{50}$ of the viral stock HIV-1 $1_{\text {Bal }}$ or medium in control wells. For each experimental condition, duplicates were performed. After 2 hours of incubation at $37^{\circ} \mathrm{C}$, tissue blocks were washed three times with $3 \mathrm{ml}$ of phosphate-buffered saline in 6-well plates and placed back in a 12-well plate at eight blocks per well in $1 \mathrm{ml}$ of R20. Infected cervical tissue blocks were cultured for additional 12 days, with a change of medium every 3 days. Tissue digestion with collagenase IV (Invitrogen) and manual dissociation were immediately carried out as previously described $(49,50)$. Cells were incubated with Aqua viability dye to distinguish dead cells and with CD45-AF700, CD19-V500, CD3-PerCP, CD4-BV605, CD8-APC, CD14-APC-H7, CD32PE-Cy7, and HLA-DR-BV421 (all from BD Biosciences). After surface staining, cells were intracellularly stained with KC57-PE antibody (Beckman Coulter) to determine p24 expression. All the events were acquired using a BD FACSAria Cell Sorter and analyzed [Flow Cytometry Platform, Germans Trias i Pujol Health Science Research Institute (IGTP)] with FlowJo vX.0.7 software (Tree Star). Gating strategy consisted of a lymphocyte gate based on forward scatter versus side scatter, followed by doublet exclusion, dead and $\mathrm{CD}_{1} 9^{+}$cells exclusion, and a $\mathrm{CD} 3^{+} \mathrm{T}$ cell gate from where the different gates shown were quantified.

\section{RNA in situ hybridization in LNs}

Paraffin-embedded LN samples from four viremic and two aviremic ART-treated HIV-infected patients and a healthy donor were obtained from the Anatomical Pathology Department of the Hospital Universitari Vall d'Hebron (Barcelona, Spain). Written informed consent was provided by all of the patients who participated in this study, and the protocols used were approved by the Comite d'Ètica d'Investigació Clínica (IRB number 196-2015) of the Hospital Universitari Vall d'Hebron (Barcelona, Spain). For detection of RNA in paraffin-embedded samples, the ultrasensitive RNA detection assay ViewRNA ISH Tissue 2-Plex Evaluation Kit (eBiosciences) was used. Two high-sensitivity target-specific sets were used: one set of 50 probes spanning the whole Gag-Pol HIV mRNA sequence (bases 1165 to 4402; reference HXB2) and another set of probes designed specifically to hybridize to human CD32a (bases 1046 to 2370; cat. no. VA63171678). LN sections of $6 \mu \mathrm{m}$ were mounted on Superfrost Plus 
microscope slides (Fisher Scientific). The assay was performed as previously described (48). Briefly, samples were deparaffinized with xylene and dehydrated with decreasing concentrations of ethanol. Section pretreatments were performed by heat-induced epitope retrieval and protease digestion. Next, probe hybridization was carried out by incubation of probes 2 hours at $40^{\circ} \mathrm{C}$, and after that, samples were stored overnight in storage buffer (eBiosciences). Finally, signal amplification was performed by sequential incubation with preamplifiers, amplifiers, and substrates. To counterstain slides, 4',6diamidino-2-phenylindole staining was performed.

\section{Confocal microscopy and quantification of in situ hybridization LN samples}

Samples were imaged on an Olympus Spectral Confocal Microscope FV1000 using a $20 \times$ and $40 \times$ phase objective and sequential mode to separately capture the fluorescence from the different fluorochromes at an image resolution of $800 \times 800$ pixels. Single HIV-1 RNA-, single CD32a RNA-, or double HIV-1 RNA/CD32a RNApositive cells were determined by visual examination of 23 to 114 B cell follicles per sample. Finally, MFI of HIV-1 RNA-positive cells and CD32a was measured in 10 to $15 \mathrm{~B}$ cell follicles using the Image software.

\section{Statistical analyses}

Data were analyzed using Prism 6.0 and 7.0 (GraphPad Software). Nonparametric Mann-Whitney $U$ tests, Wilcoxon rank tests, Spearman correlations, and Friedman tests were used, correcting for multiple comparisons with Dunnett's posttest. PCA and hierarchical clustering were performed using R-Studio.

Please refer to the Supplementary Materials for details on antibodies and staining protocols used to phenotype and sort CD $32^{+}$ $\mathrm{CD}^{+} \mathrm{T}$ cells from human blood and tissue samples, as well as from RM tissues. In addition, the Supplementary Materials contain the details of the qPCR protocols used to measure HIV DNA loads, SIV DNA loads, and cell-associated HIV RNA loads.

\section{SUPPLEMENTARY MATERIALS}

www.sciencetranslationalmedicine.org/cgi/content/full/10/437/eaar6759/DC1 Materials and Methods

Fig. S1. Representative example of the gating strategy used for analyses in Fig. 1. Fig. S2. Percentage of cells expressing the activation markers HLA-DR, CD69, or CD25 on total $\mathrm{CD}^{+} \mathrm{T}$ cells, $\mathrm{CD}_{2} 2^{+} \mathrm{CD} 4^{+} \mathrm{T}$ cells, and $\mathrm{CD}_{2} 2^{-} \mathrm{CD} 4^{+} \mathrm{T}$ cells.

Fig. S3. Phenotyping of $\mathrm{CD} 32^{+} \mathrm{CD} 4^{+}$cells from peripheral blood.

Fig. S4. Phenotyping of $\mathrm{CD}_{2} 2^{+} \mathrm{CD} 4^{+}$cells from tonsils.

Fig. S5. $\mathrm{CD} 4^{+} \mathrm{CD} 32^{+} \mathrm{T}$ cells in the LN of ART-suppressed, SIV-infected RMs are enriched in activation markers but not in SIV DNA.

Fig. S6. Lack of correlations between frequency of $\mathrm{CD} 32^{+}$of resting $\mathrm{CD} 4^{+} \mathrm{T}$ cells and HIV DNA and RNA loads.

Fig. S7. Correlations between frequency of $\mathrm{CD} 32^{-} \mathrm{CD} 4^{+} \mathrm{T}$ cells and HIV DNA and RNA loads.

Fig. S8. Different HIV RNA and CD32a RNA pattern expression in LN samples from HIV-infected patients.

Table S1. Clinical data of patients included in Figs. 1 and 5.

Table S2. DNA quantity and number of sorted cells examined in Fig. 5C.

Table S3. Clinical data of patients included in Figs. 2, 3, and 6.

Table S4. Primary data.

References (51-53)

\section{REFERENCES AND NOTES}

1. J. K. Wong, M. Hezareh, H. F. Günthard, D. V. Havlir, C. C. Ignacio, C. A. Spina,

D. D. Richman, Recovery of replication-competent HIV despite prolonged suppression of plasma viremia. Science 278, 1291-1295 (1997).

2. S. G. Deeks, HIV infection, inflammation, immunosenescence, and aging. Annu. Rev. Med. 62, 141-155 (2011).
3. J. D. Estes, C. Kityo, F. Ssali, L. Swainson, K. N. Makamdop, G. Q. Del Prete, S. G. Deeks, P. A. Luciw, J. G. Chipman, G. J. Beilman, T. Hoskuldsson, A. Khoruts, J. Anderson, C. Deleage, J. Jasurda, T. E. Schmidt, M. Hafertepe, S. P. Callisto, H. Pearson, T. Reimann, J. Schuster, J. Schoephoerster, P. Southern, K. Perkey, L. Shang, S. W. Wietgrefe, C. V. Fletcher, J. D. Lifson, D. C. Douek, J. M. McCune, A. T. Haase, T. W. Schacker, Defining total-body AIDS-virus burden with implications for curative strategies. Nat. Med. 23, 1271-1276 (2017).

4. Y. Fukazawa, R. Lum, A. A. Okoye, H. Park, K. Matsuda, J. Y. Bae, S. I. Hagen, R. Shoemaker, C. Deleage, C. Lucero, D. Morcock, T. Swanson, A. W. Legasse, M. K. Axthelm, J. Hesselgesser, R. Geleziunas, V. M. Hirsch, P. T. Edlefsen, M. Piatak Jr., J. D. Estes, J. D. Lifson, L. J. Picker, B cell follicle sanctuary permits persistent productive simian immunodeficiency virus infection in elite controllers. Nat. Med. 21, 132-139 (2015).

5. C. S. McGary, C. Deleage, J. Harper, L. Micci, S. P. Ribeiro, S. Paganini, L. Kuri-Cervantes, C. Benne, E. S. Ryan, R. Balderas, S. Jean, K. Easley, V. Marconi, G. Silvestri, J. D. Estes, R. P. Sekaly, M. Paiardini, CTLA-4 ${ }^{+} \mathrm{PD}-1^{-}$memory $\mathrm{CD} 4^{+} \mathrm{T}$ cells critically contribute to viral persistence in antiretroviral therapy-suppressed, SIV-infected rhesus macaques. Immunity 47, 776-788.e5 (2017).

6. M. Perreau, A.-L. Savoye, E. De Crignis, J.-M. Corpataux, R. Cubas, E. K. Haddad, L. De Leval, C. Graziosi, G. Pantaleo, Follicular helper T cells serve as the major CD4 T cell compartment for HIV-1 infection, replication, and production. J. Exp. Med. 210, 143-156 (2013).

7. G. M. Laird, C. K. Bullen, D. I. S. Rosenbloom, A. R. Martin, A. L. Hill, C. M. Durand, J. D. Siliciano, R. F. Siliciano, Ex vivo analysis identifies effective HIV-1 latency-reversing drug combinations. J. Clin. Invest. 125, 1901-1912 (2015).

8. J. H. Elliott, F. Wightman, A. Solomon, K. Ghneim, J. Ahlers, M. J. Cameron, M. Z. Smith, T. Spelman, J. McMahon, P. Velayudham, G. Brown, J. Roney, J. Watson, M. H. Prince, J. F. Hoy, N. Chomont, R. Fromentin, F. A. Procopio, J. Zeidan, S. Palmer, L. Odevall, R. W. Johnstone, B. P. Martin, E. Sinclair, S. G. Deeks, D. J. Hazuda, P. U. Cameron, R.-P. Sékaly, S. R. Lewin, Activation of HIV transcription with short-course vorinostat in HIV-infected patients on suppressive antiretroviral therapy. PLOS Pathog. 10, e1004473 (2014).

9. R. Olesen, S. Vigano, T. A. Rasmussen, O. S. Søgaard, Z. Ouyang, M. Buzon, A. Bashirova, M. Carrington, S. Palmer, C. R. Brinkmann, X. G. Yu, L. Østergaard, M. Tolstrup, M. Lichterfeld, Innate immune activity correlates with CD4 T cell-associated HIV-1 DNA decline during latency-reversing treatment with panobinostat. J. Virol. 89, 10176-10189 (2015).

10. A. M. Spivak, A. Andrade, E. Eisele, R. Hoh, P. Bacchetti, N. N. Bumpus, F. Emad, R. Buckheit III, E. F. McCance-Katz, J. Lai, M. Kennedy, G. Chander, R. F. Siliciano, J. D. Siliciano, S. G. Deeks, A pilot study assessing the safety and latency-reversing activity of disulfiram in HIV-1-infected adults on antiretroviral therapy. Clin. Infect. Dis. 58, 883-890 (2014).

11. N. M. Archin, R. Bateson, M. K. Tripathy, A. M. Crooks, K.-H. Yang, N. P. Dahl, M. F. Kearney, E. M. Anderson, J. M. Coffin, M. C. Strain, D. D. Richman, K. R. Robertson, A. D. Kashuba, R. J. Bosch, D. J. Hazuda, J. D. Kuruc, J. J. Eron, D. M. Margolis, HIV-1 expression within resting $\mathrm{CD}^{+}{ }^{+} \mathrm{T}$ cells after multiple doses of vorinostat. J. Infect. Dis. 210 , 728-735 (2014).

12. N. M. Archin, A. L. Liberty, A. D. Kashuba, S. K. Choudhary, J. D. Kuruc, A. M. Crooks, D. C. Parker, E. M. Anderson, M. F. Kearney, M. C. Strain, D. D. Richman, M. G. Hudgens, R. J. Bosch, J. M. Coffin, J. J. Eron, D. J. Hazuda, D. M. Margolis, Administration of vorinostat disrupts HIV-1 latency in patients on antiretroviral therapy. Nature 487, 482-485 (2012).

13. J. H. Elliott, J. H. McMahon, C. C. Chang, S. A. Lee, W. Hartogensis, N. Bumpus, R. Savic, J. Roney, R. Hoh, A. Solomon, M. Piatak, R. J. Gorelick, J. Lifson, P. Bacchetti, S. G. Deeks, S. R. Lewin, Short-term administration of disulfiram for reversal of latent HIV infection: A phase 2 dose-escalation study. Lancet HIV 2, e520-e529 (2015).

14. O. S. Søgaard, M. E. Graversen, S. Leth, R. Olesen, C. R. Brinkmann, S. K. Nissen, A. S. Kjaer, M. H. Schleimann, P. W. Denton, W. J. Hey-Cunningham, K. K. Koelsch, G. Pantaleo, K. Krogsgaard, M. Sommerfelt, R. Fromentin, N. Chomont, T. A. Rasmussen, L. Østergaard, M. Tolstrup, The depsipeptide romidepsin reverses HIV-1 latency in vivo. PLOS Pathog. 11, e1005142 (2015).

15. R. J. Biggar, A. K. Chaturvedi, J. J. Goedert, E. A. Engels; HIV/AIDS Cancer Match Study, AIDS-related cancer and severity of immunosuppression in persons with AIDS. J. Natl. Cancer Inst. 99, 962-972 (2007).

16. A. Carbone, C. C. Volpi, A. V. Gualeni, A. Gloghini, Epstein-Barr virus associated lymphomas in people with HIV. Curr. Opin. HIV AIDS 12, 39-46 (2017).

17. A. Zucchetto, S. Virdone, M. Taborelli, E. Grande, L. Camoni, M. Pappagallo, V. Regine, F. Grippo, J. Polesel, L. Dal Maso, B. Suligoi, L. Frova, D. Serraino, Non-AIDS-defining cancer mortality: Emerging patterns in the late HAART era. J. Acquir. Immune Defic. Syndr. 73, 190-196 (2016).

18. A. J. Rodger, R. Lodwick, M. Schechter, S. Deeks, J. Amin, R. Gilson, R. Paredes, E. Bakowska, F. N. Engsig, A. Phillips; INSIGHT SMART, ESPRIT Study Groups, Mortality in 
well controlled HIV in the continuous antiretroviral therapy arms of the SMART and ESPRIT trials compared with the general population. AIDS 27, 973-979 (2013).

19. S. Grinspoon, A. Carr, Cardiovascular risk and body-fat abnormalities in HIV-infected adults. N. Engl. J. Med. 352, 48-62 (2005).

20. P. W. Hunt, H. L. Cao, C. Muzoora, I. Ssewanyana, J. Bennett, N. Emenyonu, A. Kembabazi, T. B. Neilands, D. R. Bangsberg, S. G. Deeks, J. N. Martin, Impact of CD8+ T-cell activation on CD4+ T-cell recovery and mortality in HIV-infected Ugandans initiating antiretroviral therapy. AIDS 25, 2123-2131 (2011).

21. J. L. Lyons, H. Uno, P. Ancuta, A. Kamat, D. J. Moore, E. J. Singer, S. Morgello, D. Gabuzda, Plasma sCD14 is a biomarker associated with impaired neurocognitive test performance in attention and learning domains in HIV infection. J. Acquir. Immune Defic. Syndr. 57, 371-379 (2011).

22. N. G. Sandler, H. Wand, A. Roque, M. Law, M. C. Nason, D. E. Nixon, C. Pedersen, K. Ruxrungtham, S. R. Lewin, S. Emery, J. D. Neaton, J. M. Brenchley, S. G. Deeks, I. Sereti, D. C. Douek; INSIGHT SMART Study Group, Plasma levels of soluble CD14 independently predict mortality in HIV infection. J. Infect. Dis. 203, 780-790 (2011).

23. C. Tincati, G. M. Bellistrì, M. Casana, E. Merlini, L. Comi, F. Bai, E. Sinigaglia, M. Cristina, G. Carpani, T. Bini, A. D. Monforte, G. Marchetti, CD8+ hyperactivation and senescence correlate with early carotid intima-media thickness in HIV+ patients with no cardiovascular disease. J. Acquir. Immune Defic. Syndr. 51, 642-644 (2009).

24. B. Descours, G. Petitjean, J.-L. López-Zaragoza, T. Bruel, R. Raffel, C. Psomas, J. Reynes, C. Lacabaratz, Y. Levy, O. Schwartz, J. D. Lelievre, M. Benkirane, CD32a is a marker of a CD4 T-cell HIV reservoir harbouring replication-competent proviruses. Nature 543, 564-567 (2017).

25. A. K. Chauhan, Human CD4 ${ }^{+}$T-cells: A role for low-affinity Fc receptors. Front. Immunol. 7, 215 (2016).

26. M. Sandor, R. G. Lynch, Lymphocyte Fc receptors: The special case of T cells. Immunol. Today 14, 227-231 (1993).

27. W. Engelhardt, J. Matzke, R. E. Schmidt, Activation-dependent expression of low affinity IgG receptors Fc $\gamma \mathrm{RII}(\mathrm{CD} 32)$ and $\mathrm{Fc \gamma RIII(CD16)}$ in subpopulations of human T lymphocytes. Immunobiology 192, 297-320 (1995).

28. G. P. Sandilands, S. A. MacPherson, E. R. Burnett, A. J. Russell, I. Downie, R. N. M. MacSween, Differential expression of CD32 isoforms following alloactivation of human T cells. Immunology 91, 204-211 (1997).

29. G. R. Starbeck-Miller, V. P. Badovinac, D. L. Barber, J. T. Harty, Cutting edge: Expression of Fc $\gamma$ RIIB tempers memory CD8 T cell function in vivo. J. Immunol. 192, 35-39 (2014).

30. C. K. Bullen, G. M. Laird, C. M. Durand, J. D. Siliciano, R. F. Siliciano, New ex vivo approaches distinguish effective and ineffective single agents for reversing HIV-1 latency in vivo. Nat. Med. 20, 425-429 (2014).

31. T.-W. Chun, L. Carruth, D. Finzi, X. Shen, J. A. DiGiuseppe, H. Taylor, M. Hermankova, K. Chadwick, J. Margolick, T. C. Quinn, Y.-H. Kuo, R. Brookmeyer, M. A. Zeiger, P. Barditch-Crovo, R. F. Siliciano, Quantification of latent tissue reservoirs and total body viral load in HIV-1 infection. Nature 387, 183-188 (1997).

32. D. Finzi, J. Blankson, J. D. Siliciano, J. B. Margolick, K. Chadwick, T. Pierson, K. Smith, J. Lisziewicz, F. Lori, C. Flexner, T. C. Quinn, R. E. Chaisson, E. Rosenberg, B. Walker, S. Gange, J. Gallant, R. F. Siliciano, Latent infection of $\mathrm{CD}^{+}{ }^{+}$cells provides a mechanism for lifelong persistence of HIV-1, even in patients on effective combination therapy. Nat. Med. 5, 512-517 (1999).

33. D. Finzi, M. Hermankova, T. Pierson, L. M. Carruth, C. Buck, R. E. Chaisson, T. C. Quinn, K. Chadwick, J. Margolick, R. Brookmeyer, J. Gallant, M. Markowitz, D. D. Ho, D. D. Richman, R. F. Siliciano, Identification of a reservoir for HIV-1 in patients on highly active antiretroviral therapy. Science 278, 1295-1300 (1997).

34. G. M. Laird, D. I. S. Rosenbloom, J. Lai, R. F. Siliciano, J. D. Siliciano, Measuring the frequency of latent HIV-1 in resting $\mathrm{CD}^{+} \mathrm{T}$ cells using a limiting dilution coculture assay. Methods Mol. Biol. 1354, 239-253 (2016).

35. J. D. Siliciano, J. Kajdas, D. Finzi, T. C. Quinn, K. Chadwick, J. B. Margolick, C. Kovacs, S. J. Gange, R. F. Siliciano, Long-term follow-up studies confirm the stability of the latent reservoir for HIV-1 in resting CD4 ${ }^{+}$T cells. Nat. Med. 9, 727-728 (2003).

36. Y. G. Alevy, J. Tucker, T. Mohanakumar, CD32A (FcyRlla) mRNA expression and regulation in blood monocytes and cell lines. Mol. Immunol. 29, 1289-1297 (1992).

37. C. Deleage, S. W. Wietgrefe, G. Del Prete, D. R. Morcock, X. P. Hao, M. Piatak Jr., J. Bess, J. L. Anderson, K. E. Perkey, C. Reilly, J. M. McCune, A. T. Haase, J. D. Lifson, T. W. Schacker, J. D. Estes, Defining HIV and SIV reservoirs in lymphoid tissues. Pathog. Immun. 1, 68-106 (2016).

38. K. Tenner-Racz, H.-J. Stellbrink, J. van Lunzen, C. Schneider, J.-P. Jacobs, B. Raschdorff, G. Großschupff, R. M. Steinman, P. Racz, The unenlarged lymph nodes of HIV-1-infected, asymptomatic patients with high CD4 T cell counts are sites for virus replication and CD4 T cell proliferation. The impact of highly active antiretroviral therapy. J. Exp. Med. 187, 949-959 (1998).

39. M. P. Bronnimann, P. J. Skinner, E. Connick, The B-cell follicle in HIV infection: Barrier to a cure. Front. Immunol. 9, 20 (2018).
40. M. Wittner, G. A. Dunay, S. Kummer, M. Bockhorn, A. Hüfner, S. Schmiedel, O. Degen, J. van Lunzen, J. M. Eberhard, J. Schulze Zur Wiesch, CD32 expression of different memory T cell subpopulations in the blood and lymph nodal tissue of HIV patients and healthy controls correlates with immune activation. J. Acquir. Immune Defic. Syndr. 77, 345-349 (2018).

41. M. Moonis, B. Lee, R. T. Bailer, Q. Luo, L. J. Montaner, CCR5 and CXCR4 expression correlated with X4 and R5 HIV-1 infection yet not sustained replication in Th1 and Th2 cells. AIDS 15, 1941-1949 (2001).

42. N. Orlova-Fink, F. Z. Chowdhury, X. Sun, S. Harrington, E. S. Rosenberg, X. G. Yu, M. Lichterfeld, Preferential susceptibility of Th9 and Th2 CD4+ T cells to X4-tropic HIV-1 infection. AIDS 31, 2211-2215 (2017).

43. A. Gosselin, T. R. Wiche Salinas, D. Planas, V. S. Wacleche, Y. Zhang, R. Fromentin, N. Chomont, E. A. Cohen, B. Shacklett, V. Mehraj, M. P. Ghali, J.-P. Routy, P. Ancuta, HIV persists in $\mathrm{CCR}^{+} \mathrm{CD}^{+} \mathrm{T}$ cells from colon and blood during antiretroviral therapy. AIDS 31, 35-48 (2017).

44. A. Gosselin, P. Monteiro, N. Chomont, F. Diaz-Griffero, E. A. Said, S. Fonseca, V. Wacleche, M. El-Far, M.-R. Boulassel, J.-P. Routy, R.-P. Sekaly, P. Ancuta, Peripheral blood $\mathrm{CCR}^{+}{ }^{+} \mathrm{CCR}^{+}{ }^{+}$and $\mathrm{CXCR3}{ }^{+} \mathrm{CCR}^{+}{ }^{+} \mathrm{CD} 4^{+} \mathrm{T}$ cells are highly permissive to HIV-1 infection. J. Immunol. 184, 1604-1616 (2010).

45. A. Cleret-Buhot, Y. Zhang, D. Planas, J.-P. Goulet, P. Monteiro, A. Gosselin, V. S. Wacleche, C. L. Tremblay, M.-A. Jenabian, J.-P. Routy, M. El-Far, N. Chomont, E. K. Haddad, R.-P. Sekaly, P. Ancuta, Identification of novel HIV-1 dependency factors in primary $\mathrm{CCR}^{+}{ }^{+} \mathrm{CR} 6^{+} \mathrm{Th} 17$ cells via a genome-wide transcriptional approach. Retrovirology $\mathbf{1 2}$, 102 (2015).

46. A. Pincetic, S. Bournazos, D. J. DiLillo, J. Maamary, T. T. Wang, R. Dahan, B.-M. Fiebiger J. V. Ravetch, Type I and type II Fc receptors regulate innate and adaptive immunity. Nat. Immunol. 15, 707-716 (2014).

47. M.-C. Veri, S. Gorlatov, H. Li, S. Burke, S. Johnson, J. Stavenhagen, K. E. Stein, E. Bonvini, S. Koenig, Monoclonal antibodies capable of discriminating the human inhibitory Fc $\gamma$-receptor IIB (CD32B) from the activating Fc $\gamma$-receptor IIA (CD32A): Biochemical, biological and functional characterization. Immunology 121, 392-404 (2007).

48. J. Grau-Expósito, C. Serra-Peinado, L. Miguel, J. Navarro, A. Curran, J. Burgos, I. Ocaña, E. Ribera, A. Torrella, B. Planas, R. Badia, J. Castellví, V. Falcó, M. Crespo, M. J. Buzon, A novel single-cell FISH-flow assay identifies effector memory $\mathrm{CD}^{+} \mathrm{T}$ cells as a major niche for HIV-1 transcription in HIV-infected patients. mBio 8, e00876-e17 (2017).

49. J.-C. Grivel, L. Margolis, Use of human tissue explants to study human infectious agents. Nat. Protoc. 4, 256-269 (2009).

50. J. Qualai, J. Cantero, L.-X. Li, J. M. Carrascosa, E. Cabré, O. Dern, L. Sumoy, G. Requena, S. J. McSorley, M. Genescà, Adhesion molecules associated with female genital tract infection. PLOS ONE 11, e0156605 (2016).

51. F. A. Procopio, R. Fromentin, D. A. Kulpa, J. H. Brehm, A.-G. Bebin, M. C. Strain, D. D. Richman, U. O'Doherty, S. Palmer, F. M. Hecht, R. Hoh, R. J. O. Barnard, M. D. Miller, D. J. Hazuda, S. G. Deeks, R.-P. Sékaly, N. Chomont, A novel assay to measure the magnitude of the inducible viral reservoir in HIV-infected individuals. EBioMedicine 2, 874-883 (2015).

52. E. S. Ryan, L. Micci, R. Fromentin, S. Paganini, C. S. McGary, K. Easley, N. Chomont, M. Paiardini, Loss of function of intestinal IL-17 and IL-22 producing cells contributes to inflammation and viral persistence in SIV-infected rhesus macaques. PLOS Pathog. 12, e1005412 (2016).

53. Y. Nishimura, R. Sadjadpour, J. J. Mattapallil, T. Igarashi, W. Lee, A. Buckler-White, M. Roederer, T.-W. Chun, M. A. Martin, High frequencies of resting $C D 4^{+}$T cells containing integrated viral DNA are found in rhesus macaques during acute lentivirus infections. Proc. Natl. Acad. Sci. U.S.A. 106, 8015-8020 (2009).

Acknowledgments: We thank the HIV-1 patients who participated in the study and their providers; Y. A. Luna, M. F. Torres, S. P. Astorga Melendez, M. Becerril, V. Falcó, R. Willekens, and J. Navarro for referral of patients and sample collection; M. Buggert for critical evaluation of flow cytometric data; J. G. Prado for providing the viral stock R5-Bal; L. Luque and M. Fernández for technical assistance; and M. Ostrowski at the University of Toronto for providing HIV-infected PBMC samples. Funding: This work was supported by NIH R01 AI065279, U01 Al065279, and UM1 Al126620 (to L.J.M.); NIH R21 Al129636 and R21 NS106970 (to M.A.-M.); W. W. Smith Charitable Trust grant no. A17101 (to M.A.-M.); the Penn Center for AIDS Research (CFAR) (P30 Al 045008 to M.A.-M.); R21Al118411 (to M.J.B.); NIH R01 Al124843 (to V.P.); the Spanish Secretariat of Science and Innovation and FEDER funds (grants SAF2015-67334-R to M.J.B. and SAF2016-80033-R to J.M.-P.); and GeSIDA and the Spanish AIDS network Red Temática Cooperativa de nvestigación en SIDA (RD16/0025/0007 to M.J.B. and J.M.-P.). Additional support was provided by the Miguel Servet program funded by the Spanish Health Institute Carlos III (CP17/00179), the Spanish "Ministerio de Economía y Competitividad, Instituto de Salud Carlos III" (ISCIII, PI17/01470), the "Pla estratègic de recerca i innovació en salut" (PERIS), from the Catalan government for M.G., Collaboratory of AIDS Researchers for Eradication (CARE; UM1AI126619), BEAT-HIV (1UM1AI126620), the University of California, 
San Diego CFAR (Al306214), the Department of Veterans Affairs, and the James B. Pendleton Charitable Trust. Additional support was provided by The Philadelphia Foundation (Robert I. Jacobs Fund), Kean Family Professorship, Henry S. Miller Jr. and J. Kenneth Nimblett, AIDS funds from the Commonwealth of Pennsylvania and the Commonwealth Universal Research Enhancement Program, Pennsylvania Department of Health, the Penn CFAR (P30 Al 045008), and Cancer Center Grant (P30 CA10815). Author contributions: M.A.-M., L.K.-C., J.G.-E., A.M.S., R.A.N., C.T., S.K.V., L.B.G., C.S.-P., M.G., J.C., G.W., K.C., M.P., D.H., G.R.-T., B.H., P.T., J.M.-P., V.P., M.R.B., M.J.B., C.T.K., and L.J.M. designed and carried out experiments. M.A.-M., L.K.-C., J.G.-E., A.M.S., C.T., S.K.V., C.S.-P., M.G., S.V., K.C., M.P., Q.L., Y.W., D.H., G.R.-T., D.R., B.H., P.T., J.M.-P., V.P., M.J.B., M.R.B., and L.J.M. analyzed and interpreted data. P.M.D.R.E., M.G.-N., K.L., K.M., J.K I.F., G.R.-T., J.C., and P.T. selected study subjects and provided samples. M.A.-M., L.K.-C., A.M.S., J.M.-P., V.P., M.J.B., M.R.B., and L.J.M. drafted the manuscript. L.J.M. supervised/supported experimental data collection, coordinated integration of collaboration between all participating laboratories, and contributed and coordinated the drafting of the manuscript. All authors edited the final version of the manuscript. Competing interests: D.H. is a Merck employee and stockholder; I.F. served on the advisory board for Gilead Sciences and ViiV Healthcare; D.R. has consulted for Gilead, Antiva, and Monogram; and J.K. is a consultant at
Gilead Sciences. All other authors declare that they have no competing interests. Data and materials availability: The data sets generated and analyzed during the current study are included in the Supplementary Materials.

Submitted 10 December 2017

Resubmitted 15 February 2018

Accepted 27 March 2018

Published 18 April 2018

10.1126/scitransImed.aar6759

Citation: M. Abdel-Mohsen, L. Kuri-Cervantes, J. Grau-Exposito, A. M. Spivak, R. A. Nell C. Tomescu, S. K. Vadrevu, L. B. Giron, C. Serra-Peinado, M. Genescà, J. Castellví, G. Wu, P. M. Del Rio Estrada, M. González-Navarro, K. Lynn, C. T. King, S. Vemula, K. Cox, Y. Wan, Q. Li, K. Mounzer, J. Kostman, I. Frank, M. Paiardini, D. Hazuda, G. Reyes-Terán, D. Richman, B. Howell, P. Tebas, J. Martinez-Picado, V. Planelles, M. J. Buzon, M. R. Betts, L. J. Montaner, CD32 is expressed on cells with transcriptionally active HIV but does not enrich for HIV DNA in resting T cells. Sci. Transl. Med. 10, eaar6759 (2018) 


\section{Science Translational Medicine}

\section{CD32 is expressed on cells with transcriptionally active HIV but does not enrich for HIV DNA in resting $T$ cells}

Mohamed Abdel-Mohsen, Leticia Kuri-Cervantes, Judith Grau-Exposito, Adam M. Spivak, Racheal A. Nell, Costin Tomescu, Surya Kumari Vadrevu, Leila B. Giron, Carla Serra-Peinado, Meritxell Genescà, Josep Castellví, Guoxin Wu, Perla M. Del Rio Estrada, Mauricio González-Navarro, Kenneth Lynn, Colin T. King, Sai Vemula, Kara Cox, Yanmin Wan, Qingsheng Li, Karam Mounzer, Jay Kostman, lan Frank, Mirko Paiardini, Daria Hazuda, Gustavo Reyes-Terán, Douglas Richman, Bonnie Howell, Pablo Tebas, Javier Martinez-Picado, Vicente Planelles, Maria J. Buzon, Michael R. Betts and Luis J. Montaner

Sci Transl Med 10, eaar6759.

DOI: 10.1126/scitranslmed.aar6759

\section{Taking an active interest in HIV latency}

HIV cure efforts have been thwarted by an inability to target the latent reservoir, which is thought to be largely composed of resting CD4 + T cells. A recent report suggested that the Fcy receptor CD32 might be a marker of latently infected CD4 ${ }^{+} \mathrm{T}$ cells. Abdel-Mohsen et al. meticulously examined T cells from treated HIV patients across the world. They found that CD32 + HIV-infected T cells had an activated phenotype and HIV RNA, indicating active HIV transcription. In contrast, the majority of HIV DNA resided in CD32 ${ }^{-}$cells. Their results suggest that targeting CD32 ${ }^{+}$cells is unlikely to hit the HIV latent reservoir.

ARTICLE TOOLS

SUPPLEMENTARY MATERIALS http://stm.sciencemag.org/content/10/437/eaar6759

http://stm.sciencemag.org/content/suppl/2018/04/16/10.437.eaar6759.DC1
RELATED
CONTENT

REFERENCES

PERMISSIONS http://stm.sciencemag.org/content/scitransmed/10/430/eaap9927.full http://stm.sciencemag.org/content/scitransmed/10/425/eaam6354.full http://stm.sciencemag.org/content/scitransmed/9/419/eaan8848.full http://science.sciencemag.org/content/sci/361/6404/740.full http://stm.sciencemag.org/content/scitransmed/10/461/eaau4711.full $\mathrm{http}: / /$ science.sciencemag.org/content/sci/363/6428/680.full http://science.sciencemag.org/content/sci/363/6431/1021.full http://science.sciencemag.org/content/sci/363/6432/1132.full $\mathrm{http}: / /$ science.sciencemag.org/content/sci/363/6433/1260.full http://science.sciencemag.org/content/sci/364/6439/438.full http://science.sciencemag.org/content/sci/364/6439/480.full http://stm.sciencemag.org/content/scitransmed/11/513/eaaw5589.full

This article cites 53 articles, 8 of which you can access for free http://stm.sciencemag.org/content/10/437/eaar6759\#BIBL

http://www.sciencemag.org/help/reprints-and-permissions

Use of this article is subject to the Terms of Service

Science Translational Medicine (ISSN 1946-6242) is published by the American Association for the Advancement of Science, 1200 New York Avenue NW, Washington, DC 20005. 2017 () The Authors, some rights reserved; exclusive licensee American Association for the Advancement of Science. No claim to original U.S. Government Works. The title Science Translational Medicine is a registered trademark of AAAS. 